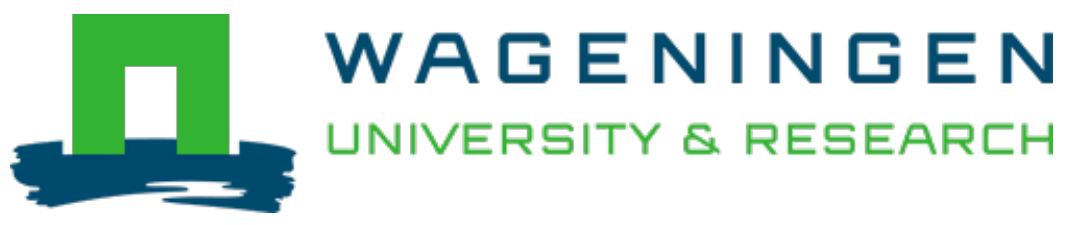

\title{
Nutritional Qualities and Enhancement of Edible Insects
}

\author{
Annual review of nutrition \\ Huis, Arnold; Rumpold, Birgit; Maya, Cassandra; Roos, Nanna \\ https://doi.org/10.1146/annurev-nutr-041520-010856
}

This publication is made publicly available in the institutional repository of Wageningen University and Research, under the terms of article $25 \mathrm{fa}$ of the Dutch Copyright Act, also known as the Amendment Taverne. This has been done with explicit consent by the author.

Article $25 \mathrm{fa}$ states that the author of a short scientific work funded either wholly or partially by Dutch public funds is entitled to make that work publicly available for no consideration following a reasonable period of time after the work was first published, provided that clear reference is made to the source of the first publication of the work.

This publication is distributed under The Association of Universities in the Netherlands (VSNU) 'Article $25 \mathrm{fa}$ implementation' project. In this project research outputs of researchers employed by Dutch Universities that comply with the legal requirements of Article $25 \mathrm{fa}$ of the Dutch Copyright Act are distributed online and free of cost or other barriers in institutional repositories. Research outputs are distributed six months after their first online publication in the original published version and with proper attribution to the source of the original publication.

You are permitted to download and use the publication for personal purposes. All rights remain with the author(s) and / or copyright owner(s) of this work. Any use of the publication or parts of it other than authorised under article $25 \mathrm{fa}$ of the Dutch Copyright act is prohibited. Wageningen University \& Research and the author(s) of this publication shall not be held responsible or liable for any damages resulting from your (re)use of this publication.

For questions regarding the public availability of this publication please contact openscience.library@,wur.nl 


\title{
'R R REVIEWS
}

\section{Annual Review of Nutrition \\ Nutritional Qualities and Enhancement of Edible Insects}

\author{
Arnold van Huis, ${ }^{1}$ Birgit Rumpold, ${ }^{2}$ Cassandra Maya, ${ }^{3}$ \\ and Nanna Roos ${ }^{3}$ \\ ${ }^{1}$ Laboratory of Entomology, Wageningen University \& Research, 6708 PB Wageningen, \\ The Netherlands; email: arnold.vanhuis@wur.nl \\ ${ }^{2}$ Department of Education for Sustainable Nutrition and Food Science, Technische Universität \\ Berlin, 10587 Berlin, Germany; email: rumpold@tu-berlin.de \\ ${ }^{3}$ Department of Nutrition, Exercise and Sports, University of Copenhagen, 1958 Frederiksberg \\ C, Denmark; email: casma@nexs.ku.dk, nro@nexs.ku.dk
}

Annu. Rev. Nutr. 2021. 41:551-76

First published as a Review in Advance on June 29, 2021

The Annual Review of Nutrition is online at nutr.annualreviews.org

https://doi.org/10.1146/annurev-nutr-041520010856

Copyright (C) 2021 by Annual Reviews. All rights reserved

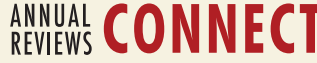

www.annualreviews.org

- Download figures

- Navigate cited references

- Keyword search

- Explore related articles

- Share via email or social media

\section{Keywords}

edible insects, entomophagy, alternative proteins, health, food safety, consumer attitudes

\section{Abstract}

Over the last decade, the urgency to find alternative and sustainable protein sources has prompted an exponential increase in the interest in insects as a human food source. Edible insects contribute suitable amounts of energy and protein, fatty acids, and micronutrients to the human diet. Nutritional values of insects can be manipulated to meet specific needs. Edible insects in food-insecure countries can contribute to improving diets and preventing undernutrition. Bioactive compounds in insects may reduce health risks. Food safety risks are low and mainly relate to those of allergenicity. Strategies to overcome barriers to the consumption of insect products include emphasizing their sustainability, increasing their tastiness, and developing the ability to disguise insects in familiar products. A new sector of insects as food and feed is emerging. Major challenges include legislation, lowering prices by automation and cheap substrates, developing insect products that appeal to consumers, and exploring the health benefits. 


\section{Contents}

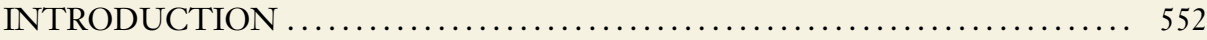

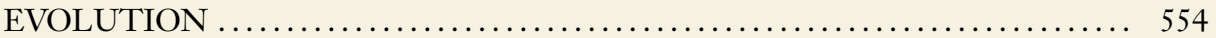

NUTRITIONAL QUALITY OF INSECTS ........................ 554

Biotic and Abiotic Effects on Nutritional Value......................... 554

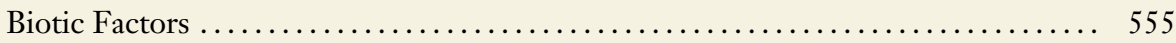

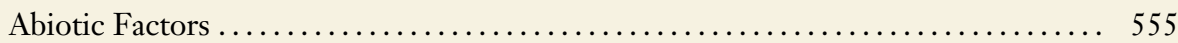

Nutritional Values .......................................... 555

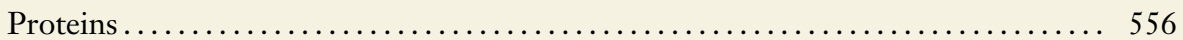

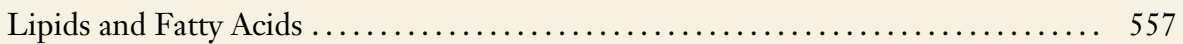

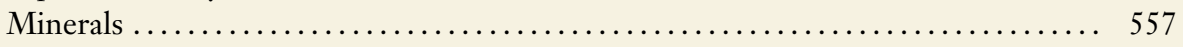

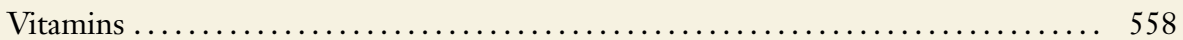

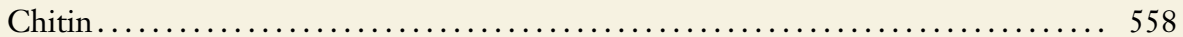

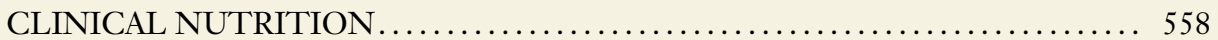

Child Malnutrition .......................................... 558

The Nutritional Role of Insects in Diets as Animal-Source Food ............. 558

Nutritional Significance of Edible Insects in Prevention

and Treatment of Malnutrition..................................... 559

Bioavailability of Minerals ....................................... 560

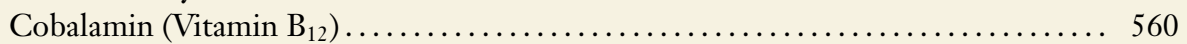

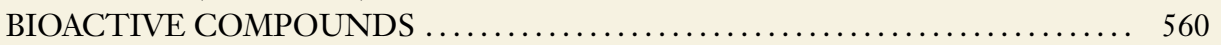

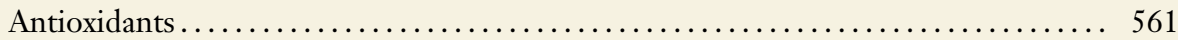

Angiotensin-Converting Enzyme and Hypertension ................... 561

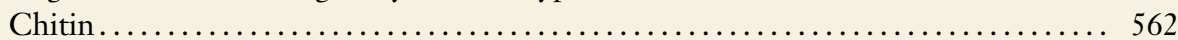

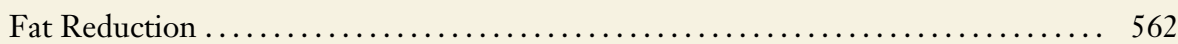

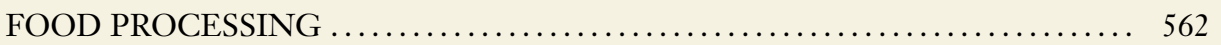

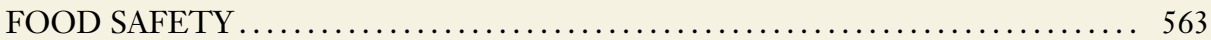

FOOD PRODUCTS CONTAINING INSECTS ....................... 564

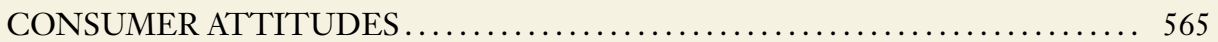

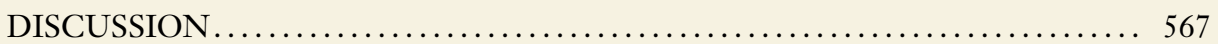

\section{INTRODUCTION}

The EAT-Lancet Commission concluded that current food systems are a major driver of poor health and environmental degradation and that there is an urgent need to transform diets and food production systems (160). Various governments have taken up the challenge and are now pursuing a policy of sustainable diets (80), defined as "diets with low environmental impacts which contribute to food and nutrition security and to healthy life for present and future generations" $(18$, p. 7). Springmann et al. (137) analyzed the food-based dietary guidelines of 85 different countries and concluded that 83 of them were not compatible with at least one of the global health and environmental targets. Regarding the environment, ruminant meat products followed by other meat and dairy products scored highest in the emission of greenhouse gases, land use, energy use, acidification potential, and eutrophication. Human health can be improved by increasing the intake of whole grains, fruits and vegetables, nuts and seeds, and legumes while reducing the intake of red and processed meat (142). The environmental impact can also be lowered by replacing meat 

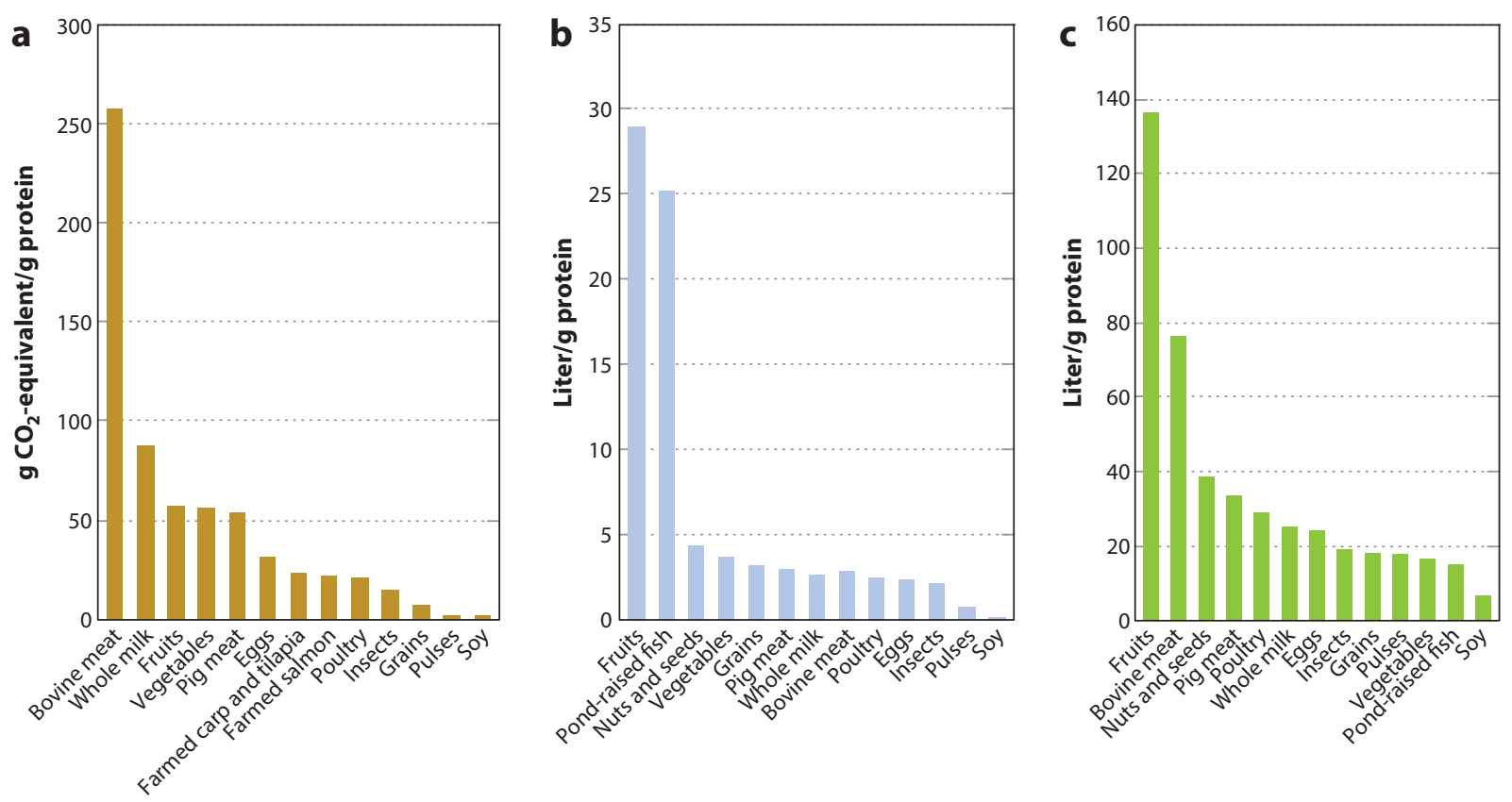

Figure 1

Footprints for selected diets (weighted averages): (a) greenhouse gas emissions (excluding emissions from land-use changes), (b) blue water (sourced from surface or groundwater resources), and (c) green water (from precipitation). Data from Reference 69.

with alternative protein sources (88), such as plant-based substitutes, insects, micro- and macroalgae, and dried cells of microorganisms (bacteria, yeast, algae, and molds). The transformation to more healthy and sustainable diets using alternative proteins is supported by a number of international organizations dealing with food, such as CGIAR (54), the Intergovernmental Panel on Climate Change (92), the Organisation for Economic Co-operation and Development, and the Food and Agriculture Organization of the United Nations (107). This change is also enhanced by a growing awareness of environmental and health issues among consumers.

The production of insects as food and feed requires less water and emits fewer greenhouse gases compared with common animal and dairy products (Figure 1) (69). It also requires less land and emits less ammonia than the production of food from common livestock species (148). Insects can also contribute to a circular economy through the biotransformation of organic waste streams into feed for monogastric animals (19) and human food (103). This benefit takes into account that one-third of all food produced for human consumption in the world is lost or wasted (35).

It is estimated that there are 5.5 million insect species worldwide, of which only about 1 million have been described (139). More than 2,000 species are known to be edible, mainly in tropical countries, and can be divided into the following categories: beetles (31\%); caterpillars (18\%); ants, bees, and wasps (15\%); grasshoppers $(14 \%)$; true bugs $(11 \%)$; dragonflies $(3 \%)$; termites (3\%); cockroaches (2\%); spiders (1\%); and others (2\%) (65). The interest worldwide during the last 10 years has focused on farming edible insects. Several species can be used as food, including the following: (a) crickets, most notably the house cricket (Acheta domesticus) and several Gryllus species [the two-spotted cricket (Gryllus bimaculatus), the Jamaican field cricket (Gryllus assimilis), and the tropical house cricket (Gryllodes sigillatus)]; (b) mealworms [the yellow mealworm (Tenebrio molitor), the lesser mealworm (Alphitobius diaperinus), and the superworm (Zophobas morio)]; (c) locust species such as the migratory locust (Locusta migratoria); and (d) several other species, 
particularly in tropical countries, such as palm weevil larvae or silkworm pupae. All farmed insects can be processed whole or the protein, fat, and chitin (exoskeleton of the insect) can be extracted.

The interest in insects as feed has focused primarily on the black soldier fly (Hermetia illucens), mainly because this insect is able to biotransform many organic side streams into insect products and contribute to a circular economy. However, this insect species also has been proposed for human consumption, although more research into the food safety is required when grown on waste (11). In this review we do not discuss the nutritional aspects of insects when used for animal feed; we only discuss those related to insects used as human food.

The increasing interest in insects as food can be demonstrated when evaluating the number of scientific articles produced worldwide during the last decade. By simply searching the words "edible insects" in the Web of Science (accessed April 15, 2021), 48 hits are recorded from 1945 to 2010, while 803 are recorded between 2011 and 2020, of which more than half are from 2019 and 2020. The number of estimated insect producers in the world has increased to 325 (updated May 26, 2021) (17). Up to early 2021, European insect-producing companies received fl1 billion in investments and in 2019 produced 600 tons of insect-based products (61).

This reflects the enormous research and economic interest in the potential of food and feed insects from a market perspective as well as a nutritional perspective. In the following sections, this interest is discussed by focusing not only on the environmental, nutritional, and health benefits but also on the process of transforming the insects into products that are appealing to consumers. Marketing strategies are discussed as well.

\section{EVOLUTION}

For early hominids, particularly for pregnant women, insects may have been an essential part of the diet (82). Because of scarce archaeological traces, insects as food for early humans have been underestimated in comparison with food plants and wild meat (95). However, there are three arguments that support insect consumption: $(a)$ archaeological evidence, $(b)$ insects being part of traditional societies' diets, and $(c)$ insects being eaten by virtually all nonhuman primates (147). Most research concerning entomophagy in the last century has focused on traditional societies that harvest insects from nature. Edible insect populations are currently threatened by overexploitation, habitat changes (deforestation), and environmental contamination (aquatic insects by pollution or edible pest insects by the use of pesticides) (150). Insects can be domesticated like honeybees or silkworms. For example, palm weevils and caterpillars are semidomesticated, which enhances their occurrence and abundance (151). However, nowadays efforts are focused on the farming of insects either in a cottage industry or an industrial enterprise.

Over time, there have been articles questioning why insects were not consumed in Western societies $(56,97)$. Then, in 2013, a report was published by the Food and Agricultural Organization of the United Nations highlighting the importance and potential of insects as a novel sustainable food and feed source, not only for traditional societies, but in a global context (149). Since then, the interest among academics and private enterprise for using insects either as food or feed has increased exponentially.

\section{NUTRITIONAL QUALITY OF INSECTS}

\section{Biotic and Abiotic Effects on Nutritional Value}

More than 2,000 insects are recorded to be eaten, and all of them differ in nutritional content. There are many influences at play here, such as biotic factors (diet, time of harvesting, gender), abiotic factors (temperature, humidity, light regime) (39), processing, and conservation. However, results also depend on which analytic method is performed. 


\section{Biotic Factors}

Diet is probably the most important factor for the nutritional value of the insect. It is possible to influence the diet to target specific needs. There is a trade-off between rearing insects on cheap diets and low performance of the insects, e.g., when attempting to rear the house cricket on organic municipal waste (86). Other cheap organic side streams can also be used, such as vegetable or fruit waste (e.g., banana, cassava, cashew) and weeds (105). Also, mealworms can be reared on organic side streams such as fruit and vegetable scraps; olive pomace; pulp flour of the palm Acrocomia aculeata; maize crop residues; and by-products from beer brewing, bread/cookie baking, potato processing, and bioethanol production (130). It is easier to change the larval fat content and profile than the protein content with diet, although the profile does not necessarily follow the same trend as dietary fatty acid composition of the substrate (146). The overly high $\omega-6 / \omega-3$ ratios in commercially produced insects can be lowered by adding flaxseed oil, a source of $\omega-3$ fatty acids, to the diet of mealworms (42) and crickets (110).

The nutritional value may also depend on the age of the insects. The protein and mineral content of the house cricket is highest before the cuticle hardens, which takes place between 9 and 11 weeks (74). Fat reserves in yellow mealworm larvae, used as an energy source during metamorphosis, increase with age (94). The lipid quality (atherogenicity and thrombogenicity) of superworm (Z. morio) larvae decreases with age (78).

Because of reproductive activities, female insects can be expected to have a better nutritional value than males. This was shown for the grasshopper Zonocerus variegatus, an appreciated food item in West Africa (2). Per $100 \mathrm{~g}$, females had more crude protein, ash, fiber, carbohydrates, and vitamins A and B than did males. For the house cricket, females had a higher energy value and contained significantly more lipids and less protein than did males (79). Besides nutritional values, gender differences may also relate to odors. For example, the male of the giant water bug Lethocerus indicus, a popular edible insect in Southeast Asia, has a unique and desirable odor (68). This flavor component is used in Thai chili paste or as an ingredient in some types of fish sauce.

\section{Abiotic Factors}

Of the abiotic factors, temperature has the most significant influence on development and survival, but it may also have an effect on the nutritional value. A trend is observed between lower fatty acid content and higher temperatures (55).

Animals (including humans) obtain vitamin $\mathrm{D}$ either by oral ingestion or by synthesizing it from ultraviolet B (UVB) light exposure. Commercially produced insects have low vitamin D concentrations, as they are not normally exposed to sunlight or other sources of UVB radiation. For the first time, Oonincx et al. (111) showed that low, but also higher intensity, UVB irradiance increased vitamin $\mathrm{D}_{3}$ levels in house crickets and yellow mealworms. In the latter species and in the migratory locust, irradiance also increased vitamin $\mathrm{D}_{2}$ levels. The levels of both vitamins $\mathrm{D}_{2}$ and $\mathrm{D}_{3}$ increased in the yellow mealworm with longer radiation up to a certain level.

\section{Nutritional Values}

In general, it is not possible to make a precise statement about the nutritional profile of edible insects. There are considerable differences between different species but also within species with regard to country of origin or region, feed composition, and whether the insects have been collected in the wild or commercially reared (128). Even the developmental stage of the insect affects the nutritional profile of insects (78). Keeping this in mind, an overview is given in this section. 


\section{Proteins}

Proteins represent the main component of the nutrient composition of insects. On average, the protein content of edible insects amounts to between $35.3 \%$ dry matter (DM) for Isoptera (termites) and $61.3 \%$ DM for Orthoptera (crickets, grasshoppers, locusts) (128).

Usually, the protein content is determined using the Kjeldahl method, where the protein content is determined by the nitrogen content multiplied by the standard nitrogen-to-protein conversion factor of 6.25. Since insect chitin also contains nitrogen, the protein content of insects in the literature has been overestimated in many cases. Janssen et al. (63) calculated a conversion factor of 4.76 for T. molitor, A. diaperinus, and H. illucens. For extracted protein from these three species, a conversion factor of 5.60 was calculated. This is in accordance with findings by Mishyna et al. (100), who estimated nitrogen-to-protein conversion factors of 4.5 for the desert locust Schistocerca gregaria and 4.9 and 5.6 for the pupae and larvae of the honeybee Apis mellifera, respectively. Boulos et al. (15) determined slightly higher nitrogen-to-protein conversion factors of 5.41, 5.25, and 5.33 for T. molitor larvae, A. domesticus, and L. migratoria, respectively. All corrected factors are well below the standard of 6.25 . Even when this overestimation in the protein content of insects is taken into consideration, the protein content is still high.

The amino acid spectra of insects generally meet the requirements for human nutrition when based on milligrams of protein per gram of DM $(113,128)$. Based on fresh weight and a portion size of $100 \mathrm{~g}$, the amino acid requirements of humans are only partly met (117). Generally, it is not possible to make a conclusive statement, since the content of essential amino acids differs both within and between insect species (117). The limiting amino acids also differ both within and between insect species $(75,108)$, and so the amino acid score (AAS) and the protein digestibility corrected amino acid score (PDCAAS) differ $(84,108,119,162)$. An overview of the AAS, PDCAAS, and limiting amino acids of exemplary edible insect species is given in Table 1. It is worth noting that the limiting amino acid of $A$. domesticus is different for three different studies.

Table 1 Amino acid score, protein digestibility corrected amino acid score, and first limiting amino acid of different insect species for human nutrition

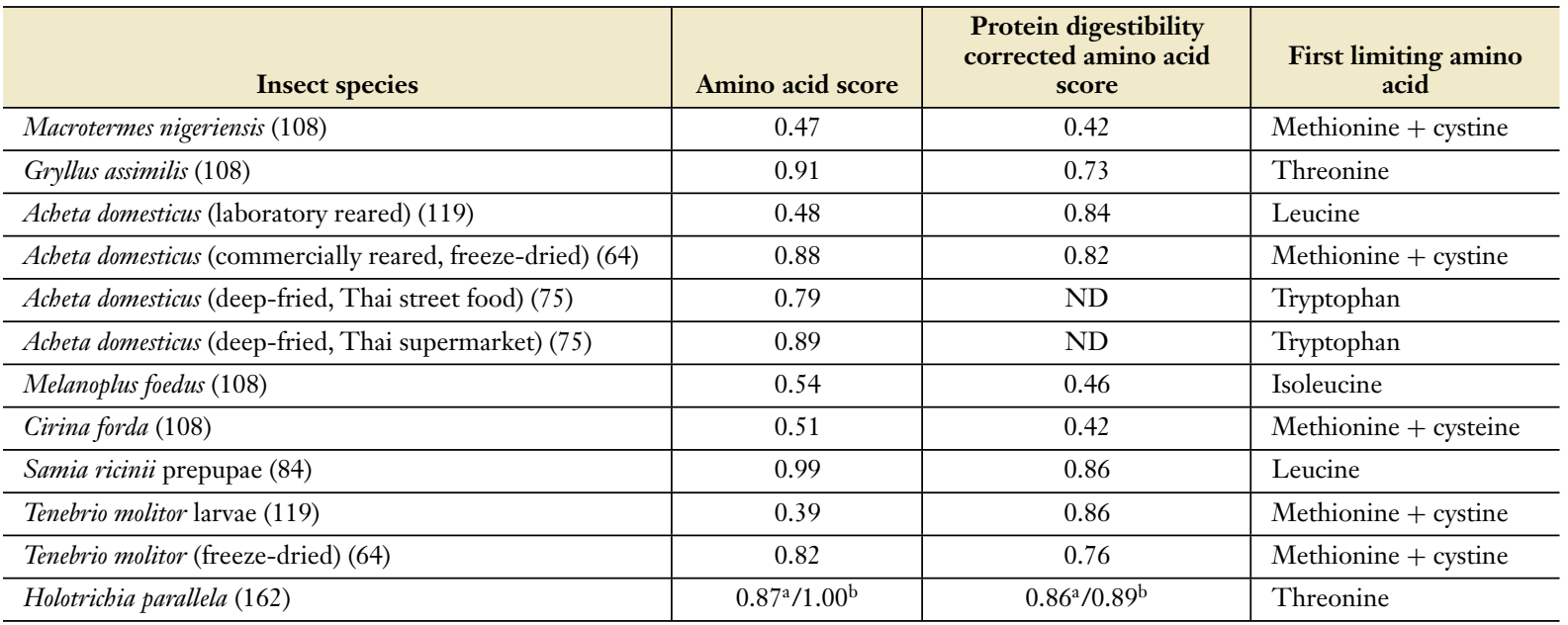

${ }^{a}$ Based on crude protein content.

${ }^{\mathrm{b}}$ Based on net protein content.

Abbreviation: ND, not determined. 


\section{Lipids and Fatty Acids}

Lipids are the second largest component of insects. Roughly, orthopterans (crickets, grasshoppers, locusts) show the lowest lipid contents with an average of $13.41 \% \mathrm{DM}$, whereas beetles, termites, and fly larvae are rich in lipids with average contents of up to $33.40 \%$ DM (128). Lipid contents as high as $77 \%$ have been found. A literature review showed that the predominant saturated fatty acids in edible insects are palmitic (C16) and stearic acid (C18). Major monounsaturated fatty acids include palmitoleic acid (C16:1n7) and oleic acid (C18:1n9). The main polyunsaturated fatty acids are linoleic acid (C18:2n6), $\alpha$-linolenic acid (C18:3n3), and $\gamma$-linolenic acid (C18:3n6) (128). It is worth noting that some insects contain lauric acid. Values as high as $48 \%$ lauric acid of the lipids were determined for H. illucens (91).

Although edible insects have a distinct fatty acid spectrum (110), it is partly dependent on the fatty acid composition of their feed $(6,33,110)$. Several studies have shown that the fatty acid spectra could be selectively enhanced via feed $(6,110)$. This is relevant since commercially produced insects are generally low in $\omega-3$ fatty acids and have elevated $\omega-6 / \omega-3$ ratios $(110)$. An $\omega-6 / \omega-3$ ratio of up to 204.15 has been found for T. molitor (mealworm larvae) (116). A comparison between three orthopterans resulted in an $\omega-6 / \omega-3$ ratio of 37.04 for $A$. domesticus, 25.08 for Conocephalus discolor, and 0.33 for Chorthippus parallelus. While the lipids of the first two orthopterans contained linoleic acid as their main fatty acid, the lipid of the latter contained $\alpha$-linolenic acid as its main fatty acid (116).

Along with the fatty acid spectra, the cholesterol contents of edible insects are also impacted by their diet. Insects need sterols for the biosynthesis of membranes and hormones. They do not synthesize cholesterol or other sterols de novo but take them up via their feed. Thus, insects feeding on animal products contain cholesterol. Also, some plant-based feeders convert plant sterols to cholesterol. However, there are a number of insect species that do not contain cholesterol (122). For example, Matthäus et al. (91) determined that $3,557 \mathrm{mg} / \mathrm{kg}$ of sterols were in the lipid fraction of $H$. illucens, of which $1,866 \mathrm{mg} / \mathrm{kg}$ were $\beta$-sitosterol and $889.7 \mathrm{mg} / \mathrm{kg}$ were campesterol.

\section{Minerals}

Comprehensive data on the mineral contents of edible insects are still scarce. It has been suggested that the mineral content of insects is dependent on and controllable via feed composition $(37,128)$. This could explain the vast variations in the literature. It also opens possibilities for edible insects to be tailored to specific dietary needs such as low-sodium or iron-rich diets.

A literature review of nutrient compositions of edible insects revealed that, on average, they are rich in copper, iron, magnesium, manganese, phosphorous, selenium, and zinc and low in calcium and potassium (128). A study on the mineral contents of the Bombay locust (Patanga succincta), the scarab beetle Holotrichia sp., A. domesticus, and the domestic silk moth (Bombyx mori) from Thailand showed that the investigated samples were either a source of or high in calcium, iron, magnesium, and zinc (75). This is in accordance with the findings of Ghosh et al. (46) who concluded that five commercially reared Korean insects were good sources of calcium, iron, and zinc. An investigation of the cricket G. sigillatus, larvae of T. molitor, and the locust $S$. gregaria showed that all three species were rich in copper, magnesium, iron, and zinc (165). This was confirmed by Fombong et al. (40), who found that the grasshopper Ruspolia differens contains high amounts of calcium, potassium, and phosphorous and is a source of iron, zinc, manganese, and copper.

Latunde-Dada et al. (81) determined and compared the contents and availability of iron, calcium, copper, magnesium, manganese, and zinc in sirloin beef and commercially reared grasshopper, cricket, yellow mealworm, and lesser mealworm. They determined that grasshopper, cricket, and mealworm contain significantly higher levels of chemically available calcium, copper, 
magnesium, manganese, and zinc than does sirloin, whereas sirloin and lesser mealworm had a higher iron than $\mathrm{FeSO}_{4}$ availability.

\section{Vitamins}

As with minerals, there are not much data to be found in the literature on the vitamin content of edible insects. Moreover, there are significant deviations in the data that are published. This is not only due to the species, its origin, and its upbringing (reared or collected in the wild) but also due to the vitamin content of the insects' feed. It has been shown that the vitamin A content of $A$. domesticus and larvae of T. molitor and B. mori could be increased via feed (37). A literature review of nutrient compositions of edible insects revealed that $100 \mathrm{~g}$ of insects based on DM is on average rich in riboflavin, pantothenic acid, and biotin (128).

\section{Chitin}

The polysaccharide chitin ( $N$-acetylglucosamine) is the main component in the insects' exoskeleton and is bound to scleroproteins. It is the second most abundant carbohydrate found in nature, following cellulose. There is no consensus on whether chitin can be metabolized by humans. A study on mammals and poultry proposed that the ability to digest chitin is dependent on feeding behavior (143). Finke (38) determined the chitin content of $H$. illucens larvae, the butterworm Chilecomadia moorei, nymphs of the cockroach Blatta lateralis, and pupae of the housefly Musca domestica and obtained chitin levels ranging between 6.7 and $21.0 \mathrm{mg} / \mathrm{kg}$ (fresh weight). A simple gravimetrical method for the determination of the chitin content of $H$. illucens larvae was proposed by Woods et al. (161) and resulted in chitin levels of $5.68 \pm 0.15 \% \mathrm{DM}$.

\section{CLINICAL NUTRITION}

\section{Child Malnutrition}

Child undernutrition remains a global burden, and the consumption of poor diets with insufficient nutrients is one of the key underlying causes. Stunting is the manifestation of chronic malnutrition resulting in retarded linear growth of the child, while wasting is acute malnutrition resulting in weight loss. Iron, zinc, and vitamin A deficiencies have been recognized as global public health problems for decades, resulting in anemia, poor growth and development, and other health consequences. Also, deficiency of vitamin $\mathrm{B}_{12}$, a vitamin that is almost exclusively available from animal-source foods, is of increasing concern in food-insecure populations.

\section{The Nutritional Role of Insects in Diets as Animal-Source Food}

Animal-source foods can improve dietary quality by providing high-quality protein and bioavailable micronutrients, thereby contributing to the improvement of nutrition in children suffering from poverty and food insecurity (26). However, animal-source foods are often expensive and inaccessible for underprivileged households. Edible insects harvested from the wild or, more recently, emerging as farmed foods offer a novel source of nutritious animal-source foods with the potential to be more accessible in nutrition-compromised populations. Despite the great variation in nutritional contents between the many edible insect species, overall, the nutritional quality of edible insects is characterized as adequate and comparable to the group of animal-source foods traditionally consumed-meat, fish, eggs, and milk. Edible insects generally contain high levels of high-quality protein (balanced amino acids) and micronutrients, while the fat content is highly variable between species. 
Compared with plant foods, the protein quality of animal-source foods is generally higher when measured by methods that combine the amino acid profile as well as the digestibility of the protein (34). As for most nutritional evaluations of edible insects, studies of protein quality evaluations are just emerging. With the current knowledge, the quality and digestibility of insect protein vary between insect species but are generally comparable with meat $(21,64,119)$. In specialized products for clinical and community treatment of severe acute malnutrition, called ready-to-use therapeutic foods (RUTF), the general recommendation by the World Health Organization is $50 \%$ of the protein originating from dairy to secure sufficient protein quality. The dairy protein can be replaced by locally available fish as an alternative low-price, high-quality protein source (133). A future scenario could be the use of farmed insects as a protein source in RUTF products for specialized treatment of severely malnourished children.

In a Western context, a crossover study $(n=6)$ in healthy young males with habitual protein intake exceeding the requirements found no difference in the amino acid response in the bloodstream after consuming insect protein (A. diaperinus), whey, or soya protein isolates (154). In South Korea, mealworm powder (T. molitor) is approved as a protein supplement to treat loss of muscle mass (sarcopenia) in the elderly and sick (70).

\section{Nutritional Significance of Edible Insects in Prevention and Treatment of Malnutrition}

In many countries where malnutrition is a problem, there is a long history of insect consumption. However, there are very few studies dealing with the nutritional impacts of insects in diets of children.

A randomized intervention study $(n=175)$ conducted in the Democratic Republic of Congo tested a locally manufactured experimental food made of a 1:1 ratio of maize and dried caterpillars (species of the family Attacidae) (9). This food was administered daily for 12 months to children recruited at the age of 12 months. In children receiving the caterpillar product, there was no effect recorded on stunting, but the prevalence of anemia was reduced when compared with children not receiving the supplement (8). A randomized controlled trial in Kenya tested experimental complementary food products, one of which contained termites (Macrotermes subbylanus) (72). It was demonstrated that termites and dagaa fish can be utilized in the production of affordable and safe complementary foods with adequate nutrient density. However, it was not possible to isolate the effect of termites, which were incorporated in a product that also included other locally available ingredients such as fish and sprouted amaranth grains. Konyole et al. (76) also studied the effect that this termite-containing food had on children recruited at the age of 6 months by comparing them with children who received a maize product fortified with micronutrients. After 9 months of the study, there was no difference in growth parameters including stunting and body composition, but the group receiving the termite-containing food had impaired iron status and a higher prevalence of anemia, suggesting inhibited iron bioavailability (76). In Cambodia, a similar study that enrolled children at the age of 6 months tested a product containing edible tarantulas (Haplopelma sp.) along with other locally available ingredients (fish and rice) (134). After 9 months of daily supplementation, this study did not find differences in growth or iron status when compared with micronutrient-fortified products. As in Kenya, the study in Cambodia was not designed specifically to isolate the impact of the tarantula. In a school-feeding trial in Kenya, biscuits with $10 \%$ flour substituted by powdered crickets (A. domesticus) were initially less accepted than similar biscuits with milk, though acceptance increased over 4 weeks of daily serving (57). In another test with children in Kenya, a porridge with $5 \%$ of the flour substituted by cricket powder resulted in an improved nutritional status similar to a milk-based porridge after 6 months of daily supplementation (73). 


\section{Bioavailability of Minerals}

These intervention studies in children are too limited and heterogeneous to draw conclusions on the nutritional impacts of edible insects. However, they do indicate that a better understanding of the bioavailability of iron and other micronutrients from insects is desirable to establish the true nutritional value of the high levels of iron and other minerals measured in many insect species (102). The iron metabolism of insects differs fundamentally from mammals. Insects do not have hemoglobin, and ferritins serve as the iron transporters, contrary to mammalian ferritins, which have a very different molecular structure, and store iron (118). These fundamental physiological differences mean that the understanding of iron bioavailability established for iron in foods originating from vertebrates and plants is not directly applicable for insects. The bioavailability of iron and other minerals including zinc in insects was assessed in an in vitro cell assay. Three species-a grasshopper, a cricket, and a mealworm—had higher contents of soluble minerals, including iron, calcium, and zinc, compared with beef. Lesser mealworms appeared to have higher iron bioavailability than did other insect species. In a single-meal study, adding isotope-labeled cricket (A. domesticus) to either refined low-phytate maize or whole-meal high-phytate maize porridges resulted in low fractional iron bioavailability (96). Also, adding cricket to a phytate-rich meal did not appear to have enhancing effects on iron bioavailability, similar to the observations in meat (5).

These results could indicate that the insects investigated in the isotope study had antinutritional properties inhibiting mineral absorption, like the well-documented inhibitory effects of polyphenols and phytic acids. Further clarifications of the nutritional value of insects as a dietary iron source rely on studies identifying such antinutritional compounds-for example, in the chitin-rich exoskeleton of the insects-and clarifying the distribution in relevant species and how contents of such antinutritional compounds may be reduced in the production or processing of the insects. The chitin content in crickets greatly depends on the stage in development when the animal is harvested (74).

\section{Cobalamin (Vitamin $\mathbf{B}_{12}$ )}

Edible insects can be considered as a source of cobalamin (vitamin $B_{12}$ ). Vitamin $B_{12}$ is synthesized in certain bacteria and is absorbed and accumulates in animals, whereupon it enters the human diet through the consumption of meat, milk, and fish. Also, certain fermented food can be a source of vitamin $B_{12}$. Bacteria in the human intestinal tract synthesize vitamin $B_{12}$, but this synthesis takes place in the colon beyond the point where nutrients are absorbed. Vitamin $B_{12}$ is essential in human metabolic processes related to blood cell formation and functionality of the nervous system. In diverse diets with a proportion of animal-source foods, vitamin $B_{12}$ is generally sufficient to meet the demands. However, the lack of or limited access to animal-source foods makes food-insecure populations vulnerable to vitamin $B_{12}$ deficiency (87). Insect species contain variable amounts of vitamin $\mathrm{B}_{12}$. A study in the grasshopper $R$. differens collected in Uganda showed that vitamin $\mathrm{B}_{12}$ content varied by a factor of two with geographic location and season (138). The bioavailability of vitamin $B_{12}$ from insect species in humans remains to be investigated.

\section{BIOACTIVE COMPOUNDS}

In addition to delivering macronutrients and micronutrients to human diets, edible insects have the potential to deliver organic compounds with bioactive impacts on human health (124). Because of the large variety of consumable insects, as well as varying nutrient levels between insects at the larval, instar, and adult stages, additional research is required to solidify claims, particularly 
on health-beneficial bioactivity. Beneficial health claims related to potential bioactive compounds in foods are covered by regulations in the European Union, United States, and other countries to protect consumers from undocumented claims (25). New findings about the potential health benefits are constantly being disclosed, and the emergence of the highly diverse food groups represented by edible insects signifies a wide area of potential bioactive compounds that need scientific validation.

\section{Antioxidants}

Antioxidants are chemical compounds that inhibit oxidation when cells are exposed to free radicals. They can be naturally present in foods or added to food products to extend shelf life or reduce health risks. Antioxidant activity in foods has led to a surge in the development of functional foods. However, antioxidant activity can be altered during digestion. Therefore, conclusions about the potential health impact in humans when assessing the antioxidative activity in in vitro assays must be interpreted with caution. The antioxidative effect needs to be documented in vivo in humans or validated animal models (145) and in future studies.

Because of their high protein content, edible insects are a potential source of a wide range of peptides, which may result in antioxidant activity. Several peptides found in edible insect species, for example, in B. mori and A. domesticus (23) and in the edible wasp Vespa affinis (28), showed antioxidant properties in in vitro studies. The exploration of the antioxidative properties of edible insects continues, with efforts to enhance antioxidant content of potential benefit for human consumption. When T. molitor was fed antioxidant-enriched diets of different fresh plant materials, growth rates improved but antioxidant activity did not increase (83). Antioxidant properties in in vitro assays of peptides present in three insect species (G. sigillatus, T. molitor, and S. gregaria) improved through heat treatments prior to digestion, such as by baking and boiling, when compared with raw insects (164). Processing methods, such as pressurized liquid extraction and ultrasoundassisted extraction, can efficiently isolate and obtain antioxidants from A. domesticus and T. molitor, which may be further improved by optimizing the solvent choice (104). Further studies are needed to explore the direct human health benefits of antioxidants found in edible insects.

\section{Angiotensin-Converting Enzyme and Hypertension}

Angiotensin-converting enzyme (ACE) inhibitors work by inhibiting the production of the enzyme angiotensin II, which subsequently inhibits vasoconstriction and prevents blood pressure from rising. ACE inhibitors are present in certain foods, such as dairy products and eggs, and are also used in medications to address cardiovascular and renal health conditions. Like antioxidants, edible insects have shown ACE-inhibitory activity due to their high protein content, but ACE activity also requires confirmation in human studies. In vitro studies have shown insects to be a potential source of ACE inhibitors. Simulated digestion with mucosal enzymes showed a successful increase in ACE inhibitory activity in cotton leafworm (Spodoptera littoralis) (155). Heat treatment (boiling) of adult $S$. gregaria resulted in higher ACE-inhibitory activities when compared with raw, baked, and protein isolation treatments (166). Inhibitory activities were also higher in $S$. gregaria than in the larvae of T. molitor and adults of $G$. sigillatus subjected to the same heat treatments. However, all heat treatments showed some positive effect on ACE-inhibition capacity in the insect species investigated (166). Also, microwave irradiation has been shown to increase ACEinhibition capacity in the cricket $G$. sigillatus (48). Some ACE inhibitors' activity may greatly vary between in vitro and in vivo studies, possibly because of modifications in the liver or interactions with other peptides (62). Moreover, the reported levels of ACE inhibition in edible insects may differ because of the lack of standardized methods (156). Further studies are required to create 
standardized methods and to explore the direct antihypertensive health benefits of edible insects in humans.

\section{Chitin}

Chitin is recognized by the immune system as a foreign substrate (31). Chitosan, made by deacetylation of chitin, is used in the pharmaceutical industry for prescription drug manufacturing as a filler, in medical treatments of wounds to stop bleeding, and in various other industrial fields. Additionally, chitosan has the potential to be an antioxidant source through modification of the molecular weight and variation of the degree of acetylation (3). Chitosan antioxidant activity increased with lower molecular weight due to the reduced occurrence of intramolecular bonds and thus higher free-radical scavenging activity (1). Typically, chitosan is derived from crustacean waste streams. The growth of insect farming, sustainability concerns, and interest in insects as human food and animal feed have led to an interest in using insect exoskeletons as a potential source of chitosan (47). The characteristics and quality of the chitosan extracted from the Goliath beetle Goliathus orientalis were similar to the chitosan extracted from shrimp (41). If functional properties are similar, insects may address the gap in chitosan supply chains caused by seasonal collection of crustaceans and provide a more sustainable alternative to fishing.

Antibacterial activity of insect-derived chitosan is dependent on structural and environmental conditions and on $\mathrm{pH}$ (suggesting stronger activity in low $\mathrm{pH}$ conditions under 6.5), is inversely related to the degree of acetylation and possibly molecular weights, and varies among bacterial species (1). Further research into various purification methods is needed to evaluate the efficacy and safety of using chitosan from insects.

A human intervention study exposing healthy adults to a daily supplement of $25 \mathrm{~g}$ of cricket (G. sigillatus) powder for 2 weeks in a crossover design showed changed microbial gut composition with enhanced growth of the probiotic bacterium Bifidobacterium animalis, which is suggested to be stimulated by the chitin in the insect supplement (140). Further research is needed to understand the potential effects of insects on gut health and the underlying mechanisms.

\section{Fat Reduction}

In view of the multiple health risks associated with overweight and obesity, insect protein and possible bioactive compounds have received attention for their possible impact on lipid metabolism. In a 4-week feeding trial on obese Zucker rats, rats were divided into four groups: lean rats fed casein (control), obese rats fed casein, obese rats fed a 50\% insect meal, and obese rats fed a $100 \%$ insect meal (45). Rats fed an insect meal had reduced liver and plasma lipid concentrates. Chitosan has been recorded to have lipid-lowering effects, but the authors could not conclude whether the observed effects were a result of insect chitin or insect protein (45). Further studies are needed to identify the benefits of edible insects on hyperlipidemia and fat reduction in humans.

\section{FOOD PROCESSING}

Food processing has several objectives: decontamination and stabilization for food safety and storage stability; separation and extraction of components, such as lipids and proteins; improvement of digestibility; enhancement of functional properties and taste; and texturization. Usually there is a trade-off between safety and nutritional and sometimes functional properties. Processing, especially thermal treatments, can have detrimental effects on food ingredients, such as vitamin loss and decreased functional properties.

Most food-processing treatments considered for treating edible insects are not new and consist of blanching, boiling, drying, grinding, centrifuging, sifting, and enzymatic treatments, among 
others. However, their impact on this novel food matrix is undetermined and needs to be further researched. For example, the chitin-containing exoskeleton of insects is unique, and it is rare that whole animals are used as food. Since whole insects still contain their gut microbiota, it is particularly important to ensure microbial safety. Otherwise there is a risk of spoilage.

Generally, it was observed that changes in insect properties upon processing are dependent not only on the processing method per se but also on the insect species $(89,100)$.

Manditsera et al. (89) investigated the effect of domestic cooking methods such as boiling, roasting, and a combination of both on the protein digestibility and mineral bioaccessibility of the beetle Eulepida mashona and the cricket Henicus whellani. They observed that boiling led to about a 50\% decrease in iron and zinc bioaccessibility in both species, while roasting did not. The authors also concluded that the protein digestibility was decreased by cooking and boiling (89). This was in accordance with the findings of Poelaert et al. (119), who determined that heat treatments negatively affect the amino acid profile and decrease nitrogen retention in rats fed with heat-treated larvae of T. molitor and the cricket $A$. domesticus.

A comparison of freeze-drying and oven-drying of blanched grasshopper $R$. differens showed no differences in nutritional quality. It was concluded that both drying methods are applicable for food insects (40).

Both an alkaline and sonication-assisted protein extraction of the locust $S$. gregaria and the brood of the honeybee $A$. mellifera led to improved emulsifying and foaming properties (100). This was in accordance with the findings of Kim et al. (71), who observed improved emulsion and foaming capacities of three edible insects upon protein extraction: T. molitor, the Japanese rhinoceros beetle (Allomyrina dichotoma), and the white-spotted flower chafer beetle (Protaetia brevitarsis). They also determined improved essential amino acid indices due to the extraction step.

Protein extraction followed by enzymatic hydrolysis of the three edible insects T. molitor larvae, G. bimaculatus, and pupae of the silkworm B. mori resulted in protein hydrolysates with a significantly higher solubility and a lower foamability compared with the respective unhydrolyzed insect proteins (163).

Comparing sensory properties of raw, steamed, roasted, and deep-fried T. molitor larvae, different aroma components and attributes were observed for raw and processed mealworms. The determined aroma attributes upon thermal reactions were very similar to those of meat and/or seafood (132). Moreover, it was observed that different drying methods led to changes in aroma at different intensities (99).

More research is still needed on the impact of different processing steps on the nutritional, sensory, and functional properties of edible insects and their products as well as on the processability of insect meal for incorporation into food products.

\section{FOOD SAFETY}

There are several safety issues related to edible insects, such as microbial, chemical, toxic, allergenic, and zoonotic risks (129).

The main microbial risks in insects are high total counts of aerobic bacteria and the presence of spore-forming bacteria that can potentially endure thermal treatments (36). Several food spoiling and pathogenic bacteria have been identified in insects. These include Bacillaceae, Enterobacteriaceae, Enterococcaceae, Staphylococcaceae, spores and spore-forming bacteria, yeast and molds (43), lactic acid bacteria, psychrotrophic aerobes, and potentially pathogenic species (44). A comprehensive overview of the microbial ecology of fresh and processed edible insects as stated in the literature is given by Garofalo et al. (44).

The microbial risks can be minimized by decontamination methods in compliance with hygiene regulations. Since insects are usually not degutted and the whole insect is consumed, the 
inactivation of the gut microbiota is crucial for microbial food safety. Fröhling et al. (43) investigated the microbial safety along the processing chain of $A$. domesticus flour and observed that the total viable count [or colony-forming unit (CFU)] was reduced from $9.24 \log _{10} \mathrm{CFU} / \mathrm{g}_{\mathrm{DM}}$ to $1.98 \log _{10} \mathrm{CFU} / \mathrm{g}_{\mathrm{DM}}$. The reduction of the total viable count was achieved during the steaming step before drying and pulverization to cricket flour. Vandeweyer et al. (153) observed that blanching and a subsequent microwave drying step of T. molitor larvae resulted in an increased reduction of total counts of up to $6.5 \mathrm{log}$ reductions with increasing drying times. However, the inactivation of bacterial spores was low, which highlighted this critical aspect of the microbial safety of edible insects. It was concluded that the microbial risk of edible insects can be limited by implementing good hygiene practices and Hazard Analysis Critical Control Point systems along the entire value chain (44).

Chemical and toxic risks include antinutrients; species-specific synthesized toxins; and the accumulation of heavy metals, toxins, and other harmful chemicals such as pesticides via feed substrate (60). Antinutrients such as tannin, oxalate, hydrocyanide, phytate, saponins, alkaloids, and heat-resistant thiaminase have been detected in varying concentrations in edible insects (60). Antinutrients in edible insects were mostly nontoxic (30,59), but the risks of antinutrients need to be considered. An investigation of the chemical contaminants of four different fly species reared on different substrates in different locations showed that, while chemical contaminants were below recommended maximum concentrations, the levels of the heavy metal cadmium raised concerns (20). The heavy metals cadmium, lead, mercury, and arsenic can accumulate in insects (60). This accumulation was also observed for pesticides (58).

The allergenic risks of food insects have two facets: the risk potential for employees in rearing facilities due to inhalation of or contact with insect materials and the risk potential for consumers upon consumption of insects (120). This review focuses on the latter. Since insects, like all arthropods, contain the allergens tropomyosin and arginine kinase, there is an allergenic potential. In addition, cross-allergic reactions to insects may occur for consumers allergic to house dust mites or crustaceans (157). Upon thermal processing like blanching, boiling, frying, or baking, the solubility of mealworm allergens was altered, but their allergenicity was not decreased (16). However, thermal processing and enzymatic hydrolysis of L. migratoria did reduce the allergic reactions of patients with house dust mite and crustacean allergies (115). More research on the speciesspecific and molecular levels is required for selective mitigation or even elimination concepts. Nevertheless, written information and warnings on food packaging containing edible insects are a prerequisite.

Since insects only transmit zoonoses as vectors, the zoonotic risks of edible insects are low when they are reared in a controlled environment (29). It was recently concluded that the hazard of food and feed insects to transmit severe acute respiratory syndrome coronavirus 2 (SARS-CoV-2) is extremely low (24).

It can be concluded that if an insect species does not produce toxins itself, and is reared in a toxic-free, hygienic environment on toxic-free, hygienic substrates according to common feed and food laws, the safety risks from edible insects are rather low. However, the allergenic potential calls for clear labeling and information.

\section{FOOD PRODUCTS CONTAINING INSECTS}

Insect products include $(a)$ whole or powdered insects; $(b)$ insects in snacks (protein bars, cookies, crisps); $(c)$ insects as meat substitutes in sausages, burgers, and schnitzels; $(d)$ insects mixed in staple foods such as pastas or bread; and $(e)$ others, such as insect cooking oil, insect-flavored liquors, and ice creams. 
In the tropics, some insects such as palm weevils, Ruspolia grasshoppers, dragonfly larvae, and the pupae from weaver ants or silkworms are sold fresh or alive in markets. Some insect species are sold dry, such as sun-dried mopane caterpillars. Other minor processing is used too, such as parboiling, smoking, roasting, stewing, frying, or a combination of these processes.

In the Western world, people are reluctant to swallow whole insects and would rather have them invisibly incorporated into familiar products. Protein bars are quite popular, and they may contain crickets or mealworms up to $20 \%$ and be flavored with cocoa, chocolate, peanuts, or fruits such as cranberries, bananas, and oranges. These flavors overpower those of the insects. Crisps with insects are marketed like the insect-free ones, with flavors such as barbecue, spicy, or sea salt.

The purpose of adding insects to staple foods, like bread or pastas, is protein enrichment. However, several attributes can change, such as nutritional value, color, cooking properties, texture, and taste, which can impact consumer acceptance. In general, a 5-10\% substitution with insect powder does not have a considerable influence on consumer acceptability. Pastas mixed with cricket powder have increased nutritional value (protein and mineral compounds), culinary properties, and texture (27). Buckwheat is gluten-free and linked to several health benefits, but the flavor is unpopular. When these buckwheat pastas were enriched with $10 \%$ silkworm powder, overall acceptance increased when compared with the insect-free product (14). The addition of mealworm to bread increased hardness and browning, and when fortified at $5 \%$, it was very comparable to the control bread sample (67). Bread fortified with $10 \%$ crickets was acceptable (10) and may even increase acceptability (114), while bread fortified with mealworms decreased overall liking (123). Bread enriched with a cockroach (Nauphoeta cinerea) did not seem to influence the sensorial qualities (22). Spore-forming bacteria in cricket-based bread loaves should be studied further (114).

Several studies have focused on insects as meat substitutes, such as mealworms in burgers (131) or black soldier fly in sausages (12). There have also been studies on whether insect oils can be used as a substitute for vegetable oils (136) or for making ice cream (90). Also, ants are being used to flavor gins (32).

Many edible insect species are considered delicious in many tropical countries. Whether deliciousness can be achieved for consumers in Western countries by product development and experimentation in culinary techniques is still being explored.

\section{CONSUMER ATTITUDES}

Sometimes it is suggested that the eating of insects in tropical countries is common practice. However, the reality is that some insect species are only consumed in certain communities, within particular ethnic groups, or in specific regions. Insects are also eaten more in rural areas than in urban areas due to availability. In general, people in the tropics are increasingly rejecting insects as food, as traditional habits are disappearing due to a changing education and Western dietary acculturation (106). Some insects may remain popular, such as termites, which appear with the first rains after the dry season, or the industrial-scale harvested and marketed grasshopper Ruspolia spp., which appears in November-December in East Africa (101). Moreover, the mopane caterpillar in southern Africa and palm weevil larvae continue to be popular food items. However, mainstream consumption is hindered by seasonal occurrence and limited availability (often only in traditional markets).

Because of the reluctance to eat insects both in the tropics and in the Western world, consumer attitudes toward commercially reared or harvested insects are universally similar. Evaluation of attitudes toward insect consumption must be gauged to develop promotional strategies. Preference for certain species depends on cultural backgrounds and individual experiences. For example, in the Netherlands there is no tradition of eating insects, as opposed to Thailand. Yet, mealworms 
sold as food in the Netherlands repulse people in Thailand because mealworms are associated with maggots in decaying matter (144). Studies about the number of people willing to try insects as food show a high variability (5-80\%) depending on the country and the research design (4).

The major challenge remains: How do consumers decide to eat something they have never eaten before, especially when it is an animal with a negative image? In the West, the awareness that insects can be eaten emerged only around a decade ago. Consequently, food neophobia, the fear and rejection of eating new or unfamiliar foods, is an issue. Also, in Western food cultures, insects are commonly perceived as a survival food, a necessity for people in tropical countries to combat starvation. Insects are currently associated with diseases and, therefore, are perceived as a food-safety risk or a nuisance. Because of this, insects are often considered emotionally as highly distasteful or disgusting.

Yet, times are changing as consumers are being exposed to a wide variety of global cuisines. In such a cosmopolitan world, consumers may be persuaded to consider insects in their diet. Food choices change over time and are driven by food innovations, trends launched by chefs or television shows, culinary innovation, and reasons related to health and the environment (4). Psychology is also involved, as information provided about edible insects influences not only the willingness to taste (127) but also the tastiness of the insect product both before tasting (131) and after tasting (141). When profiling consumers, it seems that higher education, gender (males), and younger age increase the likelihood of eating insects $(7,158)$. Insect consumers also tend to be perceived as more health-conscious, environmentally friendly, imaginative, brave, interesting, and knowledgeable than do meat consumers (50).

An insect taste experience is a good predictor for acceptability (51) and serves as motivation for the organization of bug banquets (85). Several studies, such as one by Van Thielen et al. (152), indicated that processed insects are more likely to be accepted than unprocessed ones. According to Wilkinson et al. (159), taste, appearance, safety, and quality were the main factors influencing consumer willingness to try eating insects.

Do health and sustainability properties motivate consumers? Are these reasons enough for consumers to buy insect-based products? In a survey, more than half of European consumers indicated that sustainability concerns have an influence on their eating habits, and two-thirds are open to changing their eating habits for environmental reasons (13). However, several studies have shown that environmental consciousness does not necessarily translate into an increased likelihood to consume insects in Germany (112) or Australia (135). In Europe, consumer awareness of the environmental impact of meat production is low, and consequently, so is their willingness to change to more sustainable alternatives (52).

The barriers preventing flexitarians from consuming insect products have to do with mediocre taste, high prices, and low availability (49). Concerning availability, it would certainly help if insect products were sold in supermarkets (152) with attractive packaging designs (66). Price is considered an issue and certainly is a factor when insect products are more expensive than meat (77). Although insect product companies are trying to lower consumer prices by automation processes, it is likely prices will only get substantially lower through economies of scale when there is a transformation from niche to large markets. Consumers may be willing to pay extra for insect products if there are definite health and/or environmental benefits.

Disgust and aversion toward edible insects, more than taste, are the primary motivational problems for most people (77). Perhaps the strategy should be to target only the $5-20 \%$ of health-conscious and environmentally conscious consumers willing to seek exciting, new, and novel food experiences. There is some similarity with the consumption of sushi, a food commonly met with disgust when it was first introduced (126). The flavor and texture of edible insects depend largely on the insect species, their development stage, the feeding substrate, and the 
way they are processed (98). The deliciousness of the product may be key in the acceptance of insect products, and the poor sensory evaluations should be investigated. This may be related to lipids, among other things, as defatting crickets improved overall liking and acceptability (121). However, culinary chefs and the catering industry should consider it a challenge to increase the deliciousness of insect products.

\section{DISCUSSION}

Edible insects have been a part of traditional diets in food cultures across the world. So why have insects as a potential food source been ignored for such a long time in the Western world? One practical reason is that there is much more opportunity to use them as food in tropical countries, due to the prevalence of larger insects with a clustered occurrence and year-round availability. Eating behavior and preferences are strongly influenced by upbringing, past experiences, and cultural traditions. The psychological factor of acceptance of foods is strong in any culture. In Western cultures, insects are strongly associated with diseases (as vectors), dirt and filth (cockroaches), and annoyance (houseflies). Also, in food cultures that traditionally include edible insects, the focus should be on introducing specific insect species and not a universal perception of insects being edible.

The circular economy being pursued by many governments is considered an opportunity, as food products from insects can be produced more sustainably than those from the conventional livestock industry. Therefore, in the past decade, there has been an exponential increase in the interest shown in edible insects by academics and private enterprise. Insects are now recognized as an overlooked resource of novel production systems to supply more sustainable animal-derived foods. The global climate and environmental crises require transitions of food systems, and the farming of insects can be a significant contributor in this respect. Edible insects are a potential tool for transforming organic waste into high-value proteins and food ingredients.

For insects to be considered as a meat replacement and alternative protein source, they must compete with meat as well as with plant proteins in price and nutritive value. Insect products for human consumption are generally too expensive for the retail market. Low market demand does not allow economies of scale. The price can be lowered by automating rearing processes and identifying and testing cheap organic side streams as feed substrate. Those streams should be available in reliable large quantities of constant quality and not pose any health risks. There is probably a trade-off between the cheapness of the product and the performance (survival and development) of the insect. Higher prices for insect-based products than for those of conventional foods may be justified if they are proven to be more sustainable and when health claims can be substantiated.

The nutrient and chemical content of insects greatly depends on the feed substrate. This is both an opportunity and a challenge to tailor insect nutrient profiles for groups with specific dietary needs. The uptake of these targeted nutrients from the insects' diet needs to be optimized and justify the detour via insects from both a nutritional and an economic point of view.

Novel industries require investments for the development or adaptation of techniques for rearing, processing, and conservation. However, the problem is that innovations are often kept secret or are protected by patents, often by a few large-scale companies. The growing investments in research and innovation in edible insects are now emerging; however, only a fraction of the past and continued research investment is presently established in food production systems.

On the question of processing, either whole insects or specific insect components, such as emulsifiers, gelling agents, or thickeners, can be used (93). Processing insects into safe and appealing food products meeting consumer demands continues to be challenging. Existing processing 
techniques from the food industry are available but must be tailored and optimized for the insect industry. More data are needed to assess the effect of insect processing techniques on the nutritional content. The consistency in the quality of edible insects needs to be improved. Another question is how high the percentage of insect ingredients in a food item should be before it can be called an insect-based food.

Edible insects are highly complex organisms and constitute a pool of potential bioactive compounds that can support human health and supply nutrients. Because the current evidence supports the existence of bioactivity of interest, further investigations should be conducted. Additionally, the current knowledge primarily relies on in vitro studies; therefore, human studies are required to find out whether the observations have significant health impacts.

Taste is the main driver of consumer acceptance. To reach consumers, insect-based foods should look and taste good. The current phase of innovation and market introduction covers a wide range of products with variable qualities. A more mature market for insects will help consumers to select high-quality products and allow the industry to continue to develop more attractive products. Research should continue to provide evidence for the potential health and environmental benefits of insects, which will also support the consumers in their choice. The sustainability, health, safety, and price of processed insects may be important incentives for consumers looking for alternatives to traditionally produced animal proteins (53).

How can consumers be persuaded to consume insects as a snack or a meat substitute? The psychological factors related to disgust and cultural inappropriateness should be further investigated $(109,126)$, as people may adapt to disgust $(125)$. To create market demand, the involvement of chefs, restaurateurs, the catering industry, role models, and policy makers is required. Notably, deliciousness is a prerequisite for any progress in the industry. Consumers should also be made aware of the potential health and environmental benefits.

Food insects have a tremendous potential for improving food security. They are highly nutritious and can be sustainably produced in a circular economy. Their nutrient profile can be modified and enriched for specific purposes. Moreover, bioactive compounds present in food insects can have advantageous health benefits. Because insect products have been on the market for less than a decade, legal frameworks are absent or still being conceived. The safety of insect-based products needs full attention, as food safety is closely linked to legislative approval. Safety also relates to substrates as well as to microbial risks related to processing, storing, packaging, and transport. Other challenges are economic production on an industrial scale, allergenic potential, and lack of Western consumer acceptance. Although there are still numerous research questions to be tackled, the insect industry is becoming a promising new sector in food and agriculture.

\section{DISCLOSURE STATEMENT}

The authors are not aware of any affiliations, memberships, funding, or financial holdings that might be perceived as affecting the objectivity of this review.

\section{ACKNOWLEDGMENTS}

N.R. and B.R. acknowledge funding from the European Union's Horizon 2020 research and innovation program under grant agreement 861976 (SUSINCHAIN, 2019-2023). In addition, N.R. acknowledges research grants for insects as food and feed from Danida, the Ministry of Foreign Affairs, Denmark [GREEiNSECT grant 13-06KU (2013-2018) and HEALTHYNSECT grant 19-08KU (2020-2024)]. C.M. acknowledges funding received from the European Union's Horizon 2020 research and innovation program under Marie Skłodowska-Curie grant agreement 801199 (TALENT, 2020-2023). 


\section{LITERATURE CITED}

1. Abd El-Hack ME, El-Saadony MT, Shafi ME, Zabermawi NM, Arif M, et al. 2020. Antimicrobial and antioxidant properties of chitosan and its derivatives and their applications: a review. Int. F. Biol. Macromol. 164:2726-44

2. Ademolu KO, Simbiat ES, Concilia I, Adeyinka AA, Abiodun OJ, Adebola AO. 2017. Gender variations in nutritive value of adult variegated grasshopper, Zonocerus variegatus (L) (Orthoptera: Pygomorphidae). 7. Kansas Entomol. Soc. 90:117-21

3. Anraku M, Gebicki JM, Iohara D, Tomida H, Uekama K, et al. 2018. Antioxidant activities of chitosans and its derivatives in in vitro and in vivo studies. Carbohydr: Polym. 199:141-49

4. Arena E, Mazzaglia A, Selvaggi R, Pecorino B, Fallico B, et al. 2020. Exploring consumer's propensity to consume insect-based foods. Empirical evidence from a study in southern Italy. Appl. Syst. Innov. 3(3):38

5. Bæch SB, Hansen M, Bukhave K, Jensen M, Sørensen SS, et al. 2003. Nonheme-iron absorption from a phytate-rich meal is increased by the addition of small amounts of pork meat. Am. F. Clin. Nutr. 77:17379

6. Barroso FG, Sánchez-Muros MJ, Rincón MÁ, Rodriguez M, Fabrikov D, et al. 2019. Production of n-3-rich insects by bioaccumulation of fishery waste. F. Food Comp. Anal. 82:103237

7. Bartkowicz J. 2020. Attitude toward food in aspect of risks and benefits related to the consumption of edible insects by Polish consumers. Rocz. Panśtw. Zakt. Hig. 71:67-79

8. Bauserman M, Lokangaka A, Gado J, Close K, Wallace D, et al. 2015. A cluster-randomized trial determining the efficacy of caterpillar cereal as a locally available and sustainable complementary food to prevent stunting and anaemia. Public Health Nutr. 18:1785-92

9. Bauserman M, Lokangaka A, Kodondi K-K, Gado J, Viera AJ, et al. 2015. Caterpillar cereal as a potential complementary feeding product for infants and young children: nutritional content and acceptability. Matern. Child Nutr. 11:214-20

10. Bawa M, Songsermpong S, Kaewtapee C, Chanput W. 2020. Nutritional, sensory, and texture quality of bread and cookie enriched with house cricket (Acheta domesticus) powder. F. Food Process. Preserv. 44:e14601

11. Bessa LW, Pieterse E, Marais J, Hoffman LC. 2020. Why for feed and not for human consumption? The black soldier fly larvae. Compr. Rev. Food Sci. Food Saf. 19:2747-63

12. Bessa LW, Pieterse E, Sigge G, Hoffman LC. 2019. An exploratory study into the use of black soldier fly (Hermetia illucens) larvae in the production of a Vienna-style sausage. Meat Muscle Biol. 3:289-98

13. BEUC. 2020. One bite at a time: consumers and the transition to sustainable food. Analysis of a survey of European consumers on attitudes towards sustainable food. Rep., Eur. Consum. Organ., Brussels. https://www.beuc. eu/publications/beuc-x-2020-042_consumers_and_the_transition_to_sustainable_food.pdf

14. Biró B, Fodor R, Szedljak I, Pásztor-Huszár K, Gere A. 2019. Buckwheat-pasta enriched with silkworm powder: technological analysis and sensory evaluation. LWT Food Sci. Technol. 116:108542

15. Boulos S, Tännler A, Nyström L. 2020. Nitrogen-to-protein conversion factors for edible insects on the Swiss market: T. molitor, A. domesticus, and L. migratoria. Front. Nutr. 7:89

16. Broekman H, Knulst A, den Hartog Jager S, Monteleone F, Gaspari M, et al. 2015. Effect of thermal processing on mealworm allergenicity. Mol. Nutr. Food Res. 59:1855-64

17. Bug Burger. 2020. The eating insects startups: Here is the list of entopreneurs around the world! Bug Burger, accessed on April 15, 2021. http://www.bugburger.se/foretag/the-eating-insects-startupshere-is-the-list-of-entopreneurs-around-the-world/

18. Burlingame B, Dernini S, eds. 2012. Sustainable Diets and Biodiversity. Directions and Solutions for Policy, Research and Action. Rome: Food Agric. Organ. U. N. http://www.fao.org/3/a-i3004e.pdf

19. Cappellozza S, Leonardi GM, Savoldelli S, Carminati D, Rizzolo A, et al. 2019. A first attempt to produce proteins from insects by means of a circular economy. Animals 9:278

20. Charlton AJ, Dickinson M, Wakefield ME, Fitches E, Kenis M, et al. 2015. Exploring the chemical safety of fly larvae as a source of protein for animal feed. F. Insects Food Feed 1:7-16

21. Cho KH, Kang SW, Yoo JS, Song DK, Chung YH, et al. 2020. Effects of mealworm (Tenebrio molitor) larvae hydrolysate on nutrient ileal digestibility in growing pigs compared to those of defatted mealworm larvae meal, fermented poultry by-product, and hydrolyzed fish soluble. Asian-Austr. 7. Anim. Sci. 33:490500 
22. De Oliveira LM, da Silva Lucas AJ, Cadavel CL, Mellado MS. 2017. Bread enriched with flour from cinereous cockroach (Nauphoeta cinerea). Innov. Food Sci. Emerg. Technol. 44:30-35

23. Di Mattia C, Battista N, Sacchetti G, Serafini M. 2019. Antioxidant activities in vitro of water and liposoluble extracts obtained by different species of edible insects. Front. Nutr. 6:106

24. Dicke M, Eilenberg J, Salles JF, Jensen AB, Lecocq A, et al. 2020. Edible insects unlikely to contribute to transmission of coronavirus SARS-CoV-2. F. Insects Food Feed 6:333-39

25. Domínguez Díaz L, Fernández-Ruiz V, Cámara M. 2020. An international regulatory review of food health-related claims in functional food products labeling. F. Funct. Foods 68:103896

26. Dror DK, Allen LH. 2011. The importance of milk and other animal-source foods for children in lowincome countries. Food Nutr. Bull. 32:227-43

27. Duda A, Adamczak J, Chełmińska P, Juszkiewicz J, Kowalczewski P. 2019. Quality and nutritional/ textural properties of durum wheat pasta enriched with cricket powder. Foods 8:46

28. Dutta P, Dey T, Manna P, Kalita J. 2016. Antioxidant potential of Vespa affinis L., a traditional edible insect species of north east India. PLOS ONE 11:e0156107

29. EFSA (Eur. Food Saf. Auth.). 2015. Risk profile related to production and consumption of insects as food and feed. EFSA F. 13:4257

30. Ekpo KE. 2010. Nutrient composition, functional properties and anti-nutrient content of Rhynchophorus pheonicis (F) larva. Ann. Biol. Res. 1:178-90

31. Elieh Ali Komi D, Sharma L, Dela Cruz CS. 2018. Chitin and its effects on inflammatory and immune responses. Clin. Rev. Allergy Immunol. 54:213-23

32. Evans J, Flore R, Frøst MB, Nordic Food Lab. 2017. On Eating Insects: Essays, Stories and Recipes. London: Phaidon

33. Ewald N, Vidakovic A, Langeland M, Kiessling A, Sampels S, Lalander C. 2020. Fatty acid composition of black soldier fly larvae (Hermetia illucens) - possibilities and limitations for modification through diet. Waste Manag. 102:40-47

34. FAO (Food Agric. Organ. U. N.). 2013. Dietary protein quality evaluation in buman nutrition. Report of an FAO Expert Consultation. Food Nutr. Pap. 92, Food Agric. Organ. U. N., Rome. http://www.fao.org/ ag/humannutrition/35978-02317b979a686a57aa4593304ffc17f06.pdf

35. FAO (Food Agric. Organ. U. N.). 2014. Mitigation of food wastage. Societal costs and benefits. Food Agric. Organ. U.N., Rome. http://www.fao.org/3/a-i3989e.pdf

36. Fernandez-Cassi X, Supeanu A, Vaga M, Jansson A, Boqvist S, Vagsholm I. 2019. The house cricket (Acheta domesticus) as a novel food: a risk profile. 7. Insects Food Feed 5:137-57

37. Finke MD. 2003. Gut loading to enhance the nutrient content of insects as food for reptiles: a mathematical approach. Zoo Biol. 22:147-62

38. Finke MD. 2013. Complete nutrient content of four species of feeder insects. Zoo Biol. 32:27-36

39. Finke MD, Oonincx D. 2014. Insects as food for insectivores. In Mass Production of Beneficial Organisms, ed. JA Morales-Ramos, M Guadalupe Rojas, D Shapiro-Ilan, pp. 583-616. San Diego: Academic

40. Fombong F, Van Der Borght M, Vanden Broeck J. 2017. Influence of freeze-drying and oven-drying post blanching on the nutrient composition of the edible insect Ruspolia differens. Insects 8:102

41. Fournier P, Szczepanski RC, Godeau R-P, Godeau G. 2020. Chitosan extraction from Goliathus orientalis Moser, 1909: characterization and comparison with commercially available chitosan. Biomimetics 5:15

42. Francardi V, Cito A, Fusi S, Botta M, Dreassi E. 2017. Linseed to increase n-3 fatty acids in Tenebrio molitor (Coleoptera Tenebrionidae). Redia 100:73-76

43. Fröhling A, Bußler S, Durek J, Schlüter OK. 2020. Thermal impact on the culturable microbial diversity along the processing chain of flour from crickets (Acheta domesticus). Front. Microbiol. 11:884

44. Garofalo C, Milanovic V, Cardinali F, Aquilanti L, Clementi F, Osimani A. 2019. Current knowledge on the microbiota of edible insects intended for human consumption: a state-of-the-art review. Food Res. Int. 125:108527

45. Gessner DK, Schwarz A, Meyer S, Wen G, Most E, et al. 2019. Insect meal as alternative protein source exerts pronounced lipid-lowering effects in hyperlipidemic obese Zucker rats. 7. Nutr. 149:566-77

46. Ghosh S, Lee S-M, Jung C, Meyer-Rochow VB. 2017. Nutritional composition of five commercial edible insects in South Korea. 7. Asia-Pac. Entomol. 20:686-94 
47. Hahn T, Tafia E, Paul A, Salvia R, Falabella P, Zibeka S. 2020. Current state of chitin purification and chitosan production from insects. 7. Chem. Technol. Biotechnol. 95:2775-95

48. Hall F, Liceaga A. 2020. Effect of microwave-assisted enzymatic hydrolysis of cricket (Gryllodes sigillatus) protein on ACE and DPP-IV inhibition and tropomyosin-IgG binding. 7. Funct. Foods 64:103634

49. Hartmann C, Bearth A. 2019. Bugs on the menu: drivers and barriers of consumer acceptance of insects as food. In Edible Insects in the Food Sector: Methods, Current Applications and Perspectives, ed. G Sogari, C Mora, D Menozzi, pp. 45-55. Cham, Switz.: Springer

50. Hartmann C, Ruby MB, Schmidt P, Siegrist M. 2018. Brave, health-conscious, and environmentally friendly: positive impressions of insect food product consumers. Food Q. Prefer. 68:64-71

51. Hartmann C, Shi J, Giusto A, Siegrist M. 2015. The psychology of eating insects: a cross-cultural comparison between Germany and China. Food Q. Prefer. 44:148-56

52. Hartmann C, Siegrist M. 2017. Consumer perception and behaviour regarding sustainable protein consumption: a systematic review. Trends Food Sci. Technol. 61:11-25

53. Hartmann C, Siegrist M. 2017. Insects as food: perception and acceptance. Findings from current research. Ernabr. Umsch. 64:44-50

54. Herrero MA, Thornton P, Mason-D'Croza D, Palmera J. 2019. Transforming food systems under a changing climate. Future technologies and food systems innovation for accelerating progress towards the SDGs: key messages. Rep., CGIAR Res. Prog. Clim. Change Agric. Food Secur., Wageningen, Neth. https://cgspace.cgiar.org/bitstream/handle/10568/104050/Transformation\%20Initiative\% 20Briefing\%20-\%20Tech\%20A4\%20for\%20web_repaired.pdf

55. Hoffmann KH. 1985. Metabolic and enzyme adaptation to temperature. In Environmental Physiology and Biochemistry of Insects, ed. KH Hoffmann, pp. 1-32. Berlin/Heidelberg: Springer

56. Holt VM. 1993 (1885). Why Not Eat Insects?, ed. DH Meeuws. Oxford: Thornton's

57. Homann AM, Ayieko MA, Konyole SO, Roos N. 2017. Acceptability of biscuits containing 10\% cricket (Acheta domesticus) compared to milk biscuits among 5-10-year-old Kenyan schoolchildren. F. Insects Food Feed 3:95-103

58. Houbraken M, Spranghers T, De Clercq P, Cooreman-Algoed M, Couchement T, et al. 2016. Pesticide contamination of Tenebrio molitor (Coleoptera: Tenebrionidae) for human consumption. Food Chem. 201:264-69

59. Idowu AB, Oliyide EO, Ademolu KO, Bamidele JA. 2019. Nutritional and anti-nutritional evaluation of three edible insects consumed by the Abeokuta community in Nigeria. Int. F. Trop. Insect Sci. 39:157-63

60. Imathiu S. 2020. Benefits and food safety concerns associated with consumption of edible insects. NFS 7. 18:1-11

61. IPIFF (Int. Platf. Insects Food Feed). 2021. Did you know? Int. Platf. Insects Food Feed, Brussels, accessed April 15, 2021. https://ipiff.org/

62. Iwaniak A, Minkiewicz P, Darewicz M. 2014. Food-originating ACE inhibitors, including antihypertensive peptides, as preventive food components in blood pressure reduction. Compr. Rev. Food Sci. Food Saf. 13:114-34

63. Janssen RH, Vincken J-P, Van den Broek LAM, Fogliano V, Lakemond CMM. 2017. Nitrogen-toprotein conversion factors for three edible insects: Tenebrio molitor, Alphitobius diaperinus and Hermetia illucens. F. Agric. Food Chem. 65:2275-78

64. Jensen LD, Miklos R, Dalsgaard TK, Heckmann L-H, Nørgaard J. 2019. Nutritional evaluation of common (Tenebrio molitor) and lesser (Alphitobius diaperinus) mealworms in rats and processing effect on the lesser mealworm. 7. Insects Food Feed 5:257-66

65. Jongema Y. 2019. List of edible insects of the world. Table, Lab. Entomol., Wageningen Univ., Neth. https://www.wur.nl/en/Research-Results/Chair-groups/Plant-Sciences/Laboratoryof-Entomology/Edible-insects/Worldwide-species-list.htm

66. Kauppi S-M. 2020. Packaging design strategies for introducing whole mealworms as human food. In Proceedings of NordDesign DS 101, ed. NH Mortensen, CT Hansen, M Deininger. Lyngby, Den.: Tech. Univ. Den. https://www.designsociety.org/publication/42542/Packaging+design+strategies+for+ introducing+whole+mealworms+as+human+food

67. Khuenpet K, Pakasap C, Vatthanakul S, Kitthawee S. 2020. Effect of larval-stage mealworm (Tenebrio molitor) powder on qualities of bread. Int. F. Agric. Technol. 16:283-96 
68. Kiatbenjakul P, Intarapichet K-O, Cadwallader KR. 2015. Characterization of potent odorants in male giant water bug (Lethocerus indicus Lep. and Serv.), an important edible insect of Southeast Asia. Food Chem. 168:639-47

69. Kim BF, Santo RE, Scatterday AP, Fry JP, Synk CM, et al. 2020. Country-specific dietary shifts to mitigate climate and water crises. Glob. Environ. Change 62:101926

70. Kim SH, Shon JY, Park JS, Kim JW, Kang JH, et al. 2016. Change in dietary intake and nutritional status using mealworms as hospital meal in postoperative patients. F. Korean Diet. Assoc. 22:292-309

71. Kim T-K, Yong HI, Chun HH, Lee M-A, Kim Y-B, Choi Y-S. 2020. Changes of amino acid composition and protein technical functionality of edible insects by extracting steps. F. Asia-Pac. Entomol. 23:298-305

72. Kinyuru JN, Konyole SO, Onyango-Omolo SA, Kenji GM, Onyango CA, et al. 2015. Nutrients, functional properties, storage stability and costing of complementary foods enriched with either termites and fish or commercial micronutrients. 7. Insects Food Feed 1:149-58

73. Kipkoech C. 2019. Nutrient profile, prebiotic potential of edible cricket, and effect of cricket-based porridge on growth, haemoglobin and fatty acid levels of school children. PhD Thesis, Jomo Kenyatta Univ. Agric. Technol., Juja, Kenya

74. Kipkoech C, Kinyuru JN, Imathiu S, Roos N. 2017. Use of house cricket to address food security in Kenya: "Nutrient and chitin composition of farmed crickets as influenced by age." Afr. F. Agric. Res. 12:3189-97

75. Köhler R, Kariuki L, Lambert C, Biesalski HK. 2019. Protein, amino acid and mineral composition of some edible insects from Thailand. 7. Asia-Pac. Entomol. 22:372-78

76. Konyole SO, Omollo SA, Kinyuru JN, Skau JKH, Owuor BO, et al. 2019. Effect of locally produced complementary foods on fat-free mass, linear growth, and iron status among Kenyan infants: a randomized controlled trial. Matern. Child Nutr. 15:e12836

77. Kornher L, Schellhorn M, Vetter S. 2019. Disgusting or innovative-consumer willingness to pay for insect based burger patties in Germany. Sustainability 11:1878

78. Kulma M, Kouřimská L, Homolková D, Božik M, Plachý V, Vrabec V. 2020. Effect of developmental stage on the nutritional value of edible insects. A case study with Blaberus craniifer and Zophobas morio. 7. Food Compos. Anal. 92:103570

79. Kulma M, Kouřimská L, Plachý V, Božik M, Adámková A, Vrabec V.2019. Effect of sex on the nutritional value of house cricket, Acheta domestica L. Food Chem. 272:267-72

80. Lang T, Mason P. 2018. Sustainable diet policy development: implications of multi-criteria and other approaches, 2008-2017. Proc. Nutr. Soc. 77:331-46

81. Latunde-Dada GO, Yang W, Vera Aviles M. 2016. In vitro iron availability from insects and sirloin beef. 7. Agric. Food Chem. 64:8420-24

82. Lesnik J. 2018. Edible Insects and Human Evolution. Gainesville: Univ. Press Florida

83. Liu C, Masri J, Perez V, Maya C, Zhao J. 2020. Growth performance and nutrient composition of mealworms (Tenebrio molitor) fed on fresh plant materials-supplemented diets. Foods 9:151

84. Longvah T, Mangthya K, Ramulu P. 2011. Nutrient composition and protein quality evaluation of eri silkworm (Samia ricinii) prepupae and pupae. Food Chem. 128:400-3

85. Looy H, Wood JR. 2006. Attitudes toward invertebrates: Are educational "bug banquets" effective? 7. Environ. Educ. 37:37-48

86. Lundy ME, Parrella MP. 2015. Crickets are not a free lunch: protein capture from scalable organic side-streams via high-density populations of Acheta domesticus. PLOS ONE 10:e0118785

87. Lweno ON, Sudfeld CR, Hertzmark E, Manji KP, Aboud S, et al. 2020. Vitamin B12 is low in milk of early postpartum women in urban Tanzania, and was not significantly increased by high dose supplementation. Nutrients 12:963

88. Macdiarmid JI, Whybrow S. 2019. Nutrition from a climate change perspective. Proc. Nutr. Soc. 78:38087

89. Manditsera FA, Luning PA, Fogliano V, Lakemond CMM. 2019. Effect of domestic cooking methods on protein digestibility and mineral bioaccessibility of wild harvested adult edible insects. Food Res. Int. 121:404-11

90. Mariod AA, Fadul H. 2014. Extraction and characterization of gelatin from two edible Sudanese insects and its applications in ice cream making. Food Sci. Technol. Int. 21:380-91 
91. Matthäus B, Piofczyk T, Katz H, Pudel F. 2019. Renewable resources from insects: exploitation, properties and refining of fat obtained by cold-pressing from Hermetia illucens (black soldier fly) larvae. Eur. 7. Lipid Sci. Technol. 121:1800376

92. Mbow C, Rosenzweig C, Barioni LG, Benton TG, Herrero M, et al. 2020. Food security. In Climate Change and Land: An IPCC Special Report on Climate Change, Desertification, Land Degradation, Sustainable Land Management, Food Security, and Greenhouse Gas Fluxes in Terrestrial Ecosystems, ed. PR Shukla, J Skea, E Calvo Buendia, V Masson-Delmotte, H-O Pörtner, et al., pp. 437-550. Geneva: Intergov. Panel Clim. Change

93. McClements DJ. 2020. Future foods: a manifesto for research priorities in structural design of foods. Food Funct. 11:1933

94. McClements RD, Lintzenich BA, Boardman J. 2003. A zoo-wide evaluation into the current feeder insect supplementation program at the Brookfield zoo. In Proceedings of the Nutrition Advisory Group Fifth Conference on Zoo and Wildlife Nutrition, pp. 54-59. Silver Spring, MD: Nutrition Advisory Group

95. McGrew WC. 2014. The 'other faunivory' revisited: insectivory in human and non-human primates and the evolution of human diet. F. Hum. Evol. 71:4-11

96. Melse-Boonstra A, Mwangi M, Oonincx DGAB, Van Loon JJA, Cercamondi C, et al. 2019. Fractional absorption of iron from crickets consumed with refined or whole meal maize porridge in young adult women (OR07-06-19). Curr. Dev. Nutr. 3(Suppl. 1):nzz034.OR07-06-19

97. Meyer-RochoWVB. 1976. Can insects help to ease the problem of world food shortage? Search 6:261-62

98. Mishyna M, Chen J, Benjamin O. 2019. Sensory attributes of edible insects and insect-based foods future outlooks for enhancing consumer appeal. Trends Food Sci. Technol. 95:141-48

99. Mishyna M, Haber M, Benjamin O, Martinez JJI, Chen J. 2020. Drying methods differentially alter volatile profiles of edible locusts and silkworms. F. Insects Food Feed 6:405-15

100. Mishyna M, Martinez J-JI, Chen J, Benjamin O. 2019. Extraction, characterization and functional properties of soluble proteins from edible grasshopper (Schistocerca gregaria) and honey bee (Apis mellifera). Food Res. Int. 116:697-706

101. Mmari MW, Kinyuru JN, Laswai HS, Okoth JK. 2017. Traditions, beliefs and indigenous technologies in connection with the edible longhorn grasshopper Ruspolia differens (Serville 1838) in Tanzania. 7. Ethnobiol. Ethnomed. 13:60

102. Mwangi MN, Oonincx DGAB, Stouten T, Veenenbos M, Melse-Boonstra A, et al. 2018. Insects as sources of iron and zinc in human nutrition. Nutr. Res. Rev. 31:248-55

103. Nava AL, Higareda TE, Barreto C, Rodríguez R, Márquez I, Palacios ML. 2020. Circular economy approach for mealworm industrial production for human consumption. IOP Conf. Ser. Earth Environ. Sci. 463:012087

104. Navarro del Hierro J, Gutiérrez-Docio A, Otero P, Reglero G, Martin D. 2020. Characterization, antioxidant activity, and inhibitory effect on pancreatic lipase of extracts from the edible insects Acheta domesticus and Tenebrio molitor. Food Chem. 309:125742

105. Ng'ang'a J, Imathiu S, Fombong F, Borremans A, Van Campenhout L, et al. 2020. Can farm weeds improve the growth and microbiological quality of crickets (Gryllus bimaculatus)? F. Insects Food Feed 6:199_ 209

106. Niassy S, Affognon HD, Fiaboe KKM, Akutse KS, Tanga CM, Ekesi S. 2016. Some key elements on entomophagy in Africa: culture, gender and belief. F. Insects Food Feed 2:139-44

107. OECD/FAO (Organ. Eco. Co-op. Dev./Food Agric. Organ. U. N.). 2020. OECD-FAO agricultural outlook 2020-2029. Rep., FAO, Rome. http://www.fao.org/3/ca8861en/CA8861EN.pdf

108. Oibiokpa FI, Akanya HO, Jigam AA, Saidu AN, Egwim EC. 2018. Protein quality of four indigenous edible insect species in Nigeria. Food Sci. Hum. Wellness 7:175-83

109. Onwezen MC, Van den Puttelaar J, Verain MCD, Veldkamp T. 2019. Consumer acceptance of insects as food and feed: the relevance of affective factors. Food Q. Prefer. 77:51-63

110. Oonincx DGAB, Laurent S, Veenenbos ME, Van Loon JJA. 2020. Dietary enrichment of edible insects with omega 3 fatty acids. Insect Sci. 27:500-9

111. Oonincx DGAB, Van Keulen P, Finke MD, Baines FM, Vermeulen M, Bosch G. 2018. Evidence of vitamin D synthesis in insects exposed to UVb light. Sci. Rep. 8:10807 
112. Orsi L, Voege LL, Stranieri S. 2019. Eating edible insects as sustainable food? Exploring the determinants of consumer acceptance in Germany. Food Res. Int. 125:108573

113. Osimani A, Garofalo C, Milanovic V, Taccari M, Cardinali F, et al. 2017. Insight into the proximate composition and microbial diversity of edible insects marketed in the European Union. Eur. Food Res. Technol. 243:1157-71

114. Osimani A, Milanović V, Cardinali F, Roncolini A, Garofalo C, et al. 2018. Bread enriched with cricket powder (Acheta domesticus): a technological, microbiological and nutritional evaluation. Innov. Food Sci. Emerg. Technol. 48:150-63

115. Pali-Schöll I, Meinlschmidt P, Larenas-Linnemann D, Purschke B, Hofstetter G, et al. 2019. Edible insects: cross-recognition of $\mathrm{IgE}$ from crustacean- and house dust mite allergic patients, and reduction of allergenicity by food processing. World Allergy Organ. 7. 12:45-54

116. Paul A, Frederich M, Megido RC, Alabi T, Malik P, et al. 2017. Insect fatty acids: a comparison of lipids from three orthopterans and Tenebrio molitor L. larvae. F. Asia-Pac. Entomol. 20:337-40

117. Payne CLR, Scarborough P, Rayner M, Nonaka K. 2016. A systematic review of nutrient composition data available for twelve commercially available edible insects, and comparison with reference values. Trends Food Sci. Technol. 47:69-77

118. Pham DQD, Winzerling JJ. 2010. Insect ferritins: typical or atypical? Biochim. Biophys. Acta Gen. Subj. 1800:824-33

119. Poelaert C, Francis F, Alabi T, Megido RC, Crahay B, et al. 2018. Protein value of two insects, subjected to various heat treatments, using growing rats and the protein digestibility-corrected amino acid score. 7. Insects Food Feed 4:77-87

120. Ribeiro JC, Cunha LM, Sousa-Pinto B, Fonseca J. 2017. Allergic risks of consuming edible insects: a systematic review. Mol. Nutr. Food Res. 62:1700030

121. Ribeiro JC, Lima RC, Maia MRG, Almeida AA, Fonseca AJM, et al. 2019. Impact of defatting freezedried edible crickets (Acheta domesticus and Gryllodes sigillatus) on the nutritive value, overall liking and sensory profile of cereal bars. LWT Food Sci. Technol. 113:108335

122. Ritter KS. 1990. Cholesterol and insects. Food Insects Newsl. 3:1, 5, 8

123. Roncolini A, Milanović V, Cardinali F, Osimani A, Garofalo C, et al. 2019. Protein fortification with mealworm (Tenebrio molitor L.) powder: effect on textural, microbiological, nutritional and sensory features of bread. PLOS ONE 14:e0211747

124. Roos N, Van Huis A. 2017. Consuming insects: Are there health benefits? 7. Insects Food Feed 3:225-29

125. Rozin P, Fallon AE. 1987. A perspective on disgust. Psychol. Rev. 94:23-41

126. Ruby MB, Rozin P. 2019. Disgust, sushi consumption, and other predictors of acceptance of insects as food by Americans and Indians. Food Q. Prefer. 74:155-62

127. Rumpold BA, Langen N. 2019. Potential of enhancing consumer acceptance of edible insects via information. 7. Insects Food Feed 5:45-53

128. Rumpold BA, Schlüter OK. 2013. Nutritional composition and safety aspects of edible insects. Mol. Nutr. Food Res. 57:802-23

129. Rumpold BA, Schlüter OK. 2013. Potential and challenges of insects as an innovative source for food and feed production. Innov. Food Sci. Emerg. Technol. 17:1-11

130. Ruschioni S, Loreto N, Foligni R, Mannozzi C, Raffaelli N, et al. 2020. Addition of olive pomace to feeding substrate affects growth performance and nutritional value of mealworm (Tenebrio molitor L.) larvae. Foods 9:317

131. Schouteten JJ, De Steur H, De Pelsmaeker S, Lagast S, Juvinal JG, et al. 2016. Emotional and sensory profiling of insect-, plant- and meat-based burgers under blind, expected and informed conditions. Food Q. Prefer. 52:27-31

132. Seo H, HR Kim, Cho IH. 2020. Aroma characteristics of raw and cooked Tenebrio molitor larvae (mealworms). Korean 7. Food Sci. Anim. Resourc. 40:649-58

133. Sigh S, Roos N, Chamnan C, Laillou A, Prak S, Wieringa FT. 2018. Effectiveness of a locally produced, fish-based food product on weight gain among Cambodian children in the treatment of acute malnutrition: a randomized controlled trial. Nutrients 10:909 
134. Skau JK, Touch B, Chhoun C, Chea M, Unni US, et al. 2015. Effects of animal source food and micronutrient fortification in complementary food products on body composition, iron status, and linear growth: a randomized trial in Cambodia. Am. F. Clin. Nutr. 101:742-51

135. Sogari G, Bogueva D, Marinova D. 2019. Australian consumers' response to insects as food. Agriculture 9:108

136. Son Y-J, Choi YS, Hwang I-K, Nho WC, Kim HS. 2020. Could defatted mealworm (Tenebrio molitor) and mealworm oil be used as food ingredients? Foods 9:40

137. Springmann M, Spajic L, Clark MA, Poore J, Herforth A, et al. 2020. The healthiness and sustainability of national and global food based dietary guidelines: modelling study. BM7 370:m2322

138. Ssepuuya G, Smets R, Nakimbugwe D, Van Der Borght M, Claes J. 2019. Nutrient composition of the long-horned grasshopper Ruspolia differens Serville: effect of swarming season and sourcing geographical area. Food Chem. 301:125305

139. Stork NE. 2018. How many species of insects and other terrestrial arthropods are there on earth? Annu. Rev. Entomol. 63:31-45

140. Stull VJ, Finer E, Bergmans RS, Febvre HP, Longhurst C, et al. 2018. Impact of edible cricket consumption on gut microbiota in healthy adults, a double-blind, randomized crossover trial. Sci. Rep. 8:10762

141. Suzuki S, Park J. 2018. Consumer evaluation of healthy, unpleasant-tasting food and the post-taste effect of positive information. Food Q. Prefer: 66:107-10

142. Swinburn BA, Kraak VI, Allender S, Atkins VJ, Baker PI, et al. 2019. The global syndemic of obesity, undernutrition, and climate change: The Lancet Commission report. Lancet 393:791-846

143. Tabata E, Kashimura A, Kikuchi A, Masuda H, Miyahara R, et al. 2018. Chitin digestibility is dependent on feeding behaviors, which determine acidic chitinase mRNA levels in mammalian and poultry stomachs. Sci. Rep. 8:1461

144. Tan HSG, Fischer ARH, Tinchan P, Stieger M, Steenbekkers LPA, Van Trijp HCM. 2015. Insects as food: exploring cultural exposure and individual experience as determinants of acceptance. Food Q. Prefer. 42:78-89

145. Turck D, Bresson J-L, Burlingame B, Dean T, Fairweather-Tait S, et al. 2018. Guidance for the scientific requirements for health claims related to antioxidants, oxidative damage and cardiovascular health. EFSA 7. 16:e 05136

146. Van Broekhoven S, Oonincx DGAB, Van Huis A, Van Loon JJA. 2015. Growth performance and feed conversion efficiency of three edible mealworm species (Coleoptera: Tenebrionidae) on diets composed of organic by-products. 7. Insect Physiol. 73:1-10

147. Van Huis A. 2017. Did early humans consume insects? 7. Insects Food Feed 3:161-63

148. Van Huis A. 2019. Environmental sustainability of insects as human food. In Reference Module in Food Science. Amsterdam: Elsevier. https://doi.org/10.1016/B978-0-08-100596-5.22589-4

149. Van Huis A, Van ItterbeeckJ, Klunder H, Mertens E, Halloran A, et al. 2013. Edible insects: future prospects for food and feed security. FAO For. Pap. 171, Food Agric. Organ. U. N., Rome, Wageningen Univ. Res. Cent., Wageningen, Neth. http://www.fao.org/3/i3253e/i3253e.pdf

150. Van Huis A, Oonincx DGAB. 2017. The environmental sustainability of insects as food and feed. A review. Agron. Sustain. Dev. 37:43

151. Van Itterbeeck J, Van Huis A. 2012. Environmental manipulation for edible insect procurement: a historical perspective. 7. Ethnobiol. Ethnomed. 8:3

152. Van Thielen L, Vermuyten S, Storms B, Rumpold B, Van Campenhout L. 2019. Consumer acceptance of foods containing edible insects in Belgium two years after their introduction to the market. $\mathcal{F}$. Insects Food Feed 5:35-44

153. Vandeweyer D, Lenaerts S, Callens A, Van Campenhout L. 2017. Effect of blanching followed by refrigerated storage or industrial microwave drying on the microbial load of yellow mealworm larvae (Tenebrio molitor). Food Control 71:311-14

154. Vangsoe MT, Thogersen R, Bertram HC, Heckmann L-HL, Hansen M. 2018. Ingestion of insect protein isolate enhances blood amino acid concentrations similar to soy protein in a human trial. Nutrients 10:1357

155. Vercruysse L, Smagghe G, Beckers T, Camp JV. 2009. Antioxidative and ACE inhibitory activities in enzymatic hydrolysates of the cotton leafworm, Spodoptera littoralis. Food Chem. 114:38-43 
156. Vercruysse L, Smagghe G, Herregods G, Van Camp J. 2005. ACE inhibitory activity in enzymatic hydrolysates of insect protein. F. Agric. Food Chem. 53:5207-311

157. Verhoeckx KCM, Van Broekhoven S, Den Hartog-Jager CF, Gaspari M, De Jong GAH, et al. 2014. House dust mite (Der p 10) and crustacean allergic patients may react to food containing yellow mealworm proteins. Food Chem. Toxicol. 65:364-73

158. Videbæk P, Grunert KG. 2020. Disgusting or delicious? Examining attitudinal ambivalence towards entomophagy among Danish consumers. Food Q. Prefer. 83:103913

159. Wilkinson K, Muhlhausler B, Motley C, Crump A, Bray H, Ankeny R. 2018. Australian consumers' awareness and acceptance of insects as food. Insects 9:44

160. Willett W, Rockström J, Loken B, Springmann M, Lang T, et al. 2019. Food in the anthropocene: the EAT-Lancet Commission on healthy diets from sustainable food systems. Lancet 393:447-92

161. Woods MJ, Goosen NJ, Hoffman LC, Pieterse E. 2020. A simple and rapid protocol for measuring the chitin content of Hermetia illucens (L.) (Diptera: Stratiomyidae) larvae. F. Insects Food Feed 6:285-90

162. Yang Q, Liu S, Sun J, Yu L, Zhang C, et al. 2014. Nutritional composition and protein quality of the edible beetle Holotrichia parallela. F. Insect Sci. 14:139

163. Yoon S, Wong AKN, Chae M, Auh J-H. 2019. Comparative characterization of protein hydrolysates from three edible insects: mealworm larvae, adult crickets, and silkworm pupae. Foods 8:563

164. Zielińska E, Baraniak B, Karaś M. 2017. Antioxidant and anti-inflammatory activities of hydrolysates and peptide fractions obtained by enzymatic hydrolysis of selected heat-treated edible insects. Nutrients 9:970

165. Zielińska E, Baraniak B, Karaś M, Rybczyńska K, Jakubczyk A. 2015. Selected species of edible insects as a source of nutrient composition. Food Res. Int. 77:460-66

166. Zielińska E, Karaś M, Baraniak B, Jakubczyk A. 2020. Evaluation of ACE, $\alpha$-glucosidase, and lipase inhibitory activities of peptides obtained by in vitro digestion of selected species of edible insects. Eur: Food Res. Technol. 246:1361-69 
Annual Review of Nutrition

Volume 41, 2021

\section{Contents}

A Dissenter's Journey

W. Philip T. Fames....

Ins and Outs of the TCA Cycle: The Central Role of Anaplerosis

Melissa Inigo, Stanistaw Deja, and Shawn C. Burgess ................................19

Metabolic and Signaling Roles of Ketone Bodies in Health and Disease

Patrycja Puchalska and Peter A. Crawford .........................................49

The Roles of Cytoplasmic Lipid Droplets in Modulating Intestinal

Uptake of Dietary Fat

Alyssa S. Zembroski, Changting Xiao, and Kimberly K. Bubman

Vitamin A and Vitamin E: Will the Real Antioxidant Please Stand Up?

William S. Blaner, Igor O. Shmarakov, and Maret G. Traber ....

Dietary and Physiological Effects of Zinc on the Immune System

Inga Wessels, Henrike Fosephine Fischer, and Lothar Rink

Roles of Endocannabinoids and Endocannabinoid-Like Molecules in

Energy Homeostasis and Metabolic Regulation: A Nutritional

Perspective

S.M. Khaledur Rabman, Toru Uyama, Zabir Hussain, and Natsuo Ueda

The Influence of Timing in Critical Care Nutrition

Liam McKeever, Sarah 7. Peterson, Omar Lateef, and Carol Braunschweig

Genetics of Sleep and Insights into Its Relationship with Obesity

Hassan S. Dashti and Fosé M. Ordovás

Designing Relevant Preclinical Rodent Models for Studying Links

Between Nutrition, Obesity, Metabolism, and Cancer

Elaine M. Glenny, Michael F. Coleman, Erin D. Giles, Elizabeth A. Wellberg, and Stephen D. Hursting 
Breastfeeding Beyond 12 Months: Is There Evidence for Health Impacts?

Kimberly A. Lackey, Bethaney D. Febrenkamp, Ryan M. Pace, Fanet E. Williams, Courtney L. Meehan, Mark A. McGuire, and Michelle K. McGuire

Sleep and Diet: Mounting Evidence of a Cyclical Relationship

Faris M. Zuraikat, Rebecca A. Wood, Rocío Barragán, and Marie-Pierre St-Onge .... 309

Cardiometabolic Benefits of Intermittent Fasting

Krista A. Varady, Sofia Cienfuegos, Mark Ezpeleta, and Kelsey Gabel

Effects of Evolution, Ecology, and Economy on Human Diet: Insights

from Hunter-Gatherers and Other Small-Scale Societies

Herman Pontzer and Brian M. Wood

Is Food Addictive? A Review of the Science

Asbley N. Gearbardt and Erica M. Schulte...

Adverse Effects of Medications on Micronutrient Status: From

Evidence to Guidelines

Michael S. Daniels, Brian I. Park, and Diane L. McKay

Microbial Flavonoid Metabolism: A Cardiometabolic Disease Perspective

Lucas 7. Osborn, Fan Claesen, and 7. Mark Brown

Diet-Host-Microbiota Interactions Shape Aryl Hydrocarbon

Receptor Ligand Production to Modulate Intestinal Homeostasis

Huajun Han, Stephen Safe, Arul Jayaraman, and Robert S. Chapkin

Nutritional Interventions and the Gut Microbiome in Children

Saurabb Mebta, Samantha L. Huey, Daniel McDonald, Rob Knight, and Fulia L. Finkelstein

Standardized Reference Diets for Zebrafish: Addressing Nutritional

Control in Experimental Methodology

Stephen A. Watts and Louis R. D'Abramo

The Influence of Front-of-Package Nutrition Labeling on Consumer

Behavior and Product Reformulation

Christina A. Roberto, Shu Wen Ng, Montserrat Ganderats-Fuentes,

David Hammond, Simon Barquera, Alejandra Fauregui,

and Lindsey Smith Taillie

Nutritional Qualities and Enhancement of Edible Insects

Arnold van Huis, Birgit Rumpold, Cassandra Maya, and Nanna Roos

\section{Errata}

An online log of corrections to Annual Review of Nutrition articles may be found at http://www.annualreviews.org/errata/nutr 